\title{
A sustentabilidade do desenvolvimento e a demanda material da economia: o caso do Brasil comparado ao de países industrializados
}

José Alberto da Costa Machado - Professor Adjunto da Universidade do Amazonas, Faculdade de Economia e Administração.

Norbert Fenzl - Professor Adjunto da Universidade Federal do Pará, Centro de Giociências, Núcleo de Altos Estudos Amazônicos _ NAEA e Núcleo de Meio Ambiente - NUMA.

\section{Resumo}

Este artigo trata da relação sociedade-ambiente. Busca-se, por meio da Teoria de Sistemas, estabelecer um referencial que permita o entendimento dessa relação e que possibilite o acesso operacional às suas dinâmicas. A esse arcabouço teórico é associada uma proposta metodológica que se estrutura em torno da contabilização dos fluxos materiais componentes dos processos econômicos. Desse método, o Material Flow Analysis (MFA), foi aprofundado o conceito de Metabolismo Econômico-Ambiental (MEA), por meio do qual é possível quantificar toda a matéria e energia demandada por uma economia. A análise da Demanda Material Total (DMT) possibilita o conhecimento da eficiência ecológica de qualquer processo econômico e a produção de indicadores para avaliar os impactos ambientais das atividades antrópicas. Do estudo resultou um detalhamento metodológico próprio que foi aplicado para medir a DMT do Brasil para comparações com a dos EUA, Alemanha, Japão e Holanda. Os resultados demonstraram que a metodologia é capaz de trazer à tona aspectos ecologicamente relevantes da economia, mediante os quais é possível constatar que os sistemas econômicos são configurados por lógicas crescentemente insustentáveis em relação ao ambiente.

\section{Palavras-Chave}

Material Flow Analysis (MFA), Material Flow Account (MFA), metabolismo econômico-ambiental (MEA), metabolismo socioeconômico (MSE). metabolismo social, colonização, demanda material, desenvolvimento sustentável, indicadores de sustentabilidade e medição da sustentabilidade.

\section{Abstract}

This paper deals with the relation Society-Environment. Based on the System Theory, a theoretical background is established to understand that relation and, at same time, to enable the operational access to its dynamics. Then, a methodological approach, focused on material flows accountability of the economic process, is connected to that theoretical matrix. From this approach, known as Material Flow Analysis (MFA), the Economic-Environmental Metabolism was examined in detail. This concept allows to quantify the energy and material demand of an economy. The analysis of the Total Material Demand (TMD) enables us to know the ecological efficiency of any economic process and allows us to elaborate environmental impact indicators of antropic activities. This study produced an appropriate methodology that was applied to measure the TMD of Brazil and to compare it with the TMD of the USA, Germany, Japan and The Netherlands. The results demonstrated that the methodology is capable of identifying relevant ecological features of the economy, showing that the economic system has its own logic and that in the present conditions it is increasingly unsustainable in relation to the environment.

\section{Keywords}

Material Flow Analysis (MFA), Material Flow Account (MFA), Economic-Environmental Metabolism, Economic-Social Metabolism, Social Metabolism, Colonization, Material Demand, Sustainable Development, Indicators of Sustainability and Measurement of Sustainability. 
José Alberto da Costa Machado, Norbert Fenzl

\section{Introdução}

O presente artigo foi produzido no contexto do Projeto Amazônia 21, do NAEA, financiado pelo governo da Comunidade Européia e realizado em parceria com instituições de pesquisa da Áustria, Alemanha, Brasil, Bolívia, Colômbia, Escócia, Holanda e Venezuela ${ }^{1}$.

O debate sobre a sustentabilidade da relação entre a Sociedade ${ }^{2}$ e o $A_{m b i e n t e} 3$ parece ter perdido intensidade após sua fase inicial de denúncia e diagnóstico, apesar das evidências empíricas (BROWN et al., 1998) indicando o agravamento da insustentabilidade do estilo de desenvolvimento que configura essa relação. Enquanto isso, as discussões sobre o assunto continuam permeadas por diferentes visões sobre o que gera insustentabilidade, diferentes ideários sobre desenvolvimento sustentável e diferentes focos de interesses sobre produção de indicadores de sustentabilidade. Isso dificulta o surgimento de metodologias capazes de operacionalizar tanto a análise quanto a intervenção em busca de soluções.

Atualmente, várias instituições de pesquisa na Europa ${ }^{4}$ utilizam abordagens metodológicas baseadas na contabilidade de fluxos materiais, o Material Flow Analysis (MFA) ${ }^{5}$. Essa metodologia permite acessar a relação Sociedade-Ambiente por meio de dois conceitos principais: o primeiro, o Metabolismo Econômico-Ambiental (MEA) , traz a noção de que a sociedade, por meio do sistema econômico, retira recursos do Ambiente, processa-os na intimidade de suas engrenagens e deposita-os de volta no Ambiente na forma de produtos e resíduos; o segundo, Colonização, traz a noção de que a sociedade, também mediada pelo sistema econômico e visando adequar o Ambiente aos seus

\footnotetext{
Web: http://www.amazonia21.org e http://www.ufpa.br/amazonia21.

O referencial teórico a ser apresentado na Seção 1 permitirá precisar a idéia de Sociedade utilizada pelo trabalho. Até lá, o termo Sociedade será utilizado com o sentido empregado por GIDDENS (1991:21-23) como um sistema específico de relações sociais, com unidade analítica centrada nos estados-nações (as sociedades), mas com conexões que ultrapassam o sistema sociopolítico do Estado e a ordem cultural da nação e configuram um particular sistema de relações de natureza global (a Sociedade).

${ }^{3}$ O termo Ambiente (inicial maiúscula) será usado em referência à parte da natureza com a qual as Sociedades interagem. Em sua idéia não se inclui a concepção de um âmbito intocado e sim de uma paisagem ambiental aculturada, sentido que não pode ser expressado por uma palavra única, tal como " kulturlandschaft" do idioma alemão. Já "ambiente natural" (em minúsculas) será usado em referência aos espaços planetários sem interferência antrópica. Outros termos correlacionados, tais como "ambiente" e "ambiente relevante" (em minúsculas), com significados específicos na Teoria de Sistemas, serão definidos na Seção 1

${ }^{4}$ IFF (Institute of Interdisciplinary Research), na Áustria, Centre of Environmental Science, na Holanda, Wuppertal Institute for Climate, Environment and Energy, na Alemanha, e outros.

5 Na literatura técnica, é também conhecido como Material Flow Account. Maiores informações sobre o MFA podem ser obtidas em FISCHER-KOWALSKI (1998) e FISCHER-KOWALSKI (1999a). As instituições acima mencionadas dedicaram um amplo esforço, nas últimas décadas, para consolidar uma base científica para analisar os fluxos energéticos e materiais das economias dos seus respectivos países.

6 A literatura usa os termos Metabolismo Social ou Metabolismo Socioeconômico (FISCHER-KOWALSKI et al., 1991; FISCHER-KOWALSKI, HABERL e PAYER, 1992; FISCHER-KOWALSKI e HABERL, 1992). Entretanto, pelo entendimento deste trabalho, a dinâmica assim nominada ocorre entre o sistema econômico e o Ambiente, por isso, a opção pelos termos Metabolismo Econômico-Ambiental. Na Seção 1, essa opção terminológica será melhor fundamentada.
} 
interesses, intervém nele, transformando-o para o atendimento de suas necessidades exclusivas, em prejuízo de outras espécies.

O Material Flow Analysis (MFA) possibilita a análise do sistema econômico por meio de seus fluxos materiais e não somente dos fluxos monetários, como ocorre com os instrumentos clássicos. Por isso, ele permite medir a intensidade material da economia, a racionalidade da utilização dos recursos naturais e o tamanho das mochilas ecológicas ${ }^{7}$. Informações dessa natureza permitem conhecer o peso ambiental dos processos econômicos e viabilizam a construção de indicadores de sustentabilidade, com base empírica consistente.

O propósito deste trabalho é aprofundar o exame dessa metodologia e testar suas possibilidades para determinar o Metabolismo Econômico-Ambiental (MEA) do sistema econômico do Brasil a fim de compará-lo com o de países industrializados como os EUA, a Alemanha, o Japão e a Holanda. No detalhamento referido, espera-se estabelecer um quadro teórico que fundamente o método e permita estabelecer referenciais consistentes e suficientes para tratar, de forma operacional, das causas da insustentabilidade, do ideário do desenvolvimento sustentável e dos indicadores de sustentabilidade do desenvolvimento.

A comprovação da eficácia do método, em escalas nacionais, legitimará sua utilização, em etapa posterior, para a análise específica das questões de sustentabilidade na Amazônia. Pressupõe-se que o conhecimento sobre o caráter do Metabolismo Econômico-Ambiental (MEA) da região venha a fundamentar políticas públicas concretas capazes de modificar as dinâmicas econômicas nocivas ao Ambiente sem impedir a possibilidade do desenvolvimento econômico ${ }^{8}$.

\section{Bases teóricas}

\subsection{A Teoria de Sistemas}

O MFA é um método que se filia à Teoria de Sistemas ${ }^{9}$. Nesta, a realidade é formada por um número infinito de dinâmicas, cada uma podendo ser vista como um todo homogêneo, estruturado em torno de configurações e coerências próprias. Essas dinâmicas estariam em per-

\footnotetext{
7 Trata-se da quantidade de matéria que é mobilizada pela economia mas que não se integra aos produtos gerados. Na seção que detalha a metodologia, esse conceito será tratado como fluxos ignorados e será melhor definido.

8 A idéia de desenvolvimento econômico neste trabalho inclui não somente o crescimento econômico, mas também a conservação do meio ambiente e a promoção de justiça social nos termos apresentados por UNDP (1996), embora BRITO (1997) considere que no discurso do desenvolvimento, seja qual for a vertente, o pano de fundo é sempre a ênfase no crescimento da produtividade e da renda apoiada por um progresso tecnológico sem limites.

9 Essa teoria tem sido tratada como forma de pensar a realidade que só ganha concretude quando associada a um particular campo do conhecimento e que, nessas circunstâncias, assumiria o rigor e as características do campo de conhecimento hospedeiro. Entretanto, modernamente, a Teoria de Sistemas é um campo autônomo de conhecimento, com referenciais próprios, que, em relação às demais áreas, comparece como uma metateoria portadora de uma particular cosmovisão.
} 


\section{José Alberto da Costa Machado, Norbert Fenzl}

manente e mútua interação, cada qual atuando, ao mesmo tempo, na condição de parte constituinte de umas e de todo constituidor em relação a outras (LASZLO, 1996:4-10). Um estado qualquer do mundo real seria então uma configuração provisória originada da acomodação temporária entre essas dinâmicas.

Com base nessa concepção geral, qualquer dinâmica coerente, configurada em torno de um modelo organizador ${ }^{10}$ que lhe dá individualidade, identidade e sentido, é chamada de sistema (BERTALANFFY, 1976:1, RAPOPORT, 1976:21). Essa noção de sistema, na qual o todo tem significado diferente da soma das partes, surgiu como alternativa à concepção mecanicista do universo ${ }^{11}$. Nesta, a idéia de sistema, enquanto conceito para dar identidade a porções do mundo real, segundo FENZL (1997b:5), expressava-se como uma simples junção de partes componentes, sem que o todo resultante tivesse qualquer qualidade nova. Posteriormente, Ludwig Boltzmann, em seus estudos sobre entropia, estabeleceu que os estados de um sistema eram decorrentes de combinações específicas de estados particulares dos seus elementos componentes, incluindo assim, no trato com o conceito, uma dimensão espaço-tempo do âmbito específico das partes constituintes ${ }^{12}$. Com o advento da ecologia e seu conceito basilar de ecossistema, o ambiente do sistema passou também a integrar sua noção, estendendo a amplitude do conceito para uma dimensão externa ao simples limite estrutural, isso porque o sistema tanto configura quanto é configurado pelo seu ambiente. Assim, na idéia de sistema, estão associadas três dimensões.

a) A dimensão microscópica tem seu foco no "espaço interno" do sistema, isto é, nos elementos que o compõem.

b) A dimensão mesoscópica é expressada pelo conjunto de elementos que dão visibilidade à sua existência. Representa a fronteira estrutural do sistema e é a dimensão através da qual ele é referenciado. Essa fronteira estrutural atua como divisória e interface para o intercâmbio de energia e matéria entre o "espaço interno" e o "espaço externo" do sistema. Também exerce o papel de protetora da coerência interna à medida que atua como sensor e filtro em relação a tudo quanto, importado do "espaço externo", possa afetar a organização interna do sistema.

\footnotetext{
${ }^{10}$ LASZLO (1996:17) utiliza o conceito de invariâncias de organização para expressar o mesmo sentido.

${ }^{11}$ NORGAARD (1992:29) propõe um conjunto de fatores para distinguir a visão mecanicista do universo da moderna visão sistêmica, a saber: ao atomismo contrapõe o holismo, ao mecanicismo contrapõe o multimodelismo, ao universalismo contrapõe o contextualismo, ao objetivismo contrapõe o subjetivismo, ao monismo contrapõe o pluralismo. Uma síntese desses conceitos pode ser vista em MACHADO (1999:24-Nota 10). LASZLO (1996:10) adiciona outras diferenças, como a natureza eurocêntrica e antropocêntrica e o potencial de indução ao superconsumo e acumulação da visão clássica.

${ }^{12}$ Boltzman relaciona as dimensões micro e macroscópica de um sistema por meio de $S=k \cdot \log w$. Isso significa que a entropia de um sistema depende de $w$ (probabilidade) que expressa a quantidade de microestados que o sistema pode assumir sem haver colapso de sua macroestrutura.
} 
c) A dimensão macroscópica é aquela que se expressa para além da fronteira estrutural do sistema. Trata-se do ambiente relevante, isto é, de uma porção específica do "espaço externo" do sistema de onde ele retira os recursos energéticos-materiais para sua manutenção e crescimento e onde deposita os rejeitos produzidos pelo seu metabolismo energético-material ${ }^{13}$. Esse ambiente relevante também representa o espaço que o sistema utiliza para expandir sua fronteira estrutural por meio da formatação, no interesse de suas necessidades, de porções cada vez maiores desse espaço. Essa dimensão, também chamada de campo de interação ${ }^{14}$, representa a fronteira do sistema, isto é, o limite no espaço-tempo até ao qual um sistema é capaz de exportar sua configuração e de onde ele importa configurações estrangeiras. De natureza difusa, essa fronteira representa, na verdade, a adição do campo de interação à fronteira estrutural do sistema.

Os sistemas naturais ${ }^{15}$ podem ser classificados ${ }^{16}$, conforme sugerem PRIGOGINE e STENGERS (1984), em função do tipo de relação desenvolvida com seu ambiente relevante, a saber: sistemas abertos que trocam energia e matéria com seu ambiente, sistemas fechados que trocam apenas energia com o ambiente ${ }^{17}$, e sistemas isolados que nada trocam com o ambiente ${ }^{18}$. Neste trabalho, quando não explicitamente observado, a idéia de sistemas será a de sistemas abertos. Tais sistemas têm um modo de funcionamento dependente de sua estrutura, que é o arcabouço organizador que integra e confere coerência aos elementos componentes de sua organização interna, e que lhe atribui uma particular identidade e um específico comportamento.

A evolução de um sistema aberto ocorre pela necessidade que o sistema tem de lidar com mudanças em seu ambiente relevante. Se essas mudanças são pequenas, ele apenas ajusta parâmetros de funcionamento e essa evolução é chamada de adaptação; se a mudança no

\footnotetext{
${ }^{13}$ Metabolismo é conceito da biologia referente aos processos internos que mantêm um organismo vivo em funcionamento. Nas abordagens sistêmicas, esse termo é utilizado de forma mais ampla e refere-se a todos os processos de transformação e trocas de energia e matéria que ocorrem no interior de um sistema aberto e entre este e seu ambiente. Possivelmente, esse significado mais amplo decorre da origem grega do termo (meta-ballw) que guardava a idéia de "mudar, trocar de estado, transformarse; fazer trocas e comerciar" (YARZA, 1995).

${ }^{14}$ Uma descrição detalhada de campo de interação pode ser encontrada em FENZL (1997a).

${ }^{15}$ Embora existam sistemas feitos pelo homem, como as máquinas e os softwares, os conceitos a serem utilizados referir-seão aos sistemas naturais, isto é, àqueles que fazem parte do funcionamento do ambiente material e do ambiente social.

${ }^{16}$ Quando não citados, os conceitos a serem apresentados foram baseados em FENZL (1995b), FENZL (1997b) e MACHADO (1998a).

${ }^{17}$ Um exemplo é a Terra. Ela recebe energia solar e exporta para o espaço a energia que não foi utilizada ou que escapou dos seus processos internos.

${ }^{18}$ Tais sistemas existem em função da energia que, por alguma razão, já esteja circulando em seu interior. Na prática, com exceção do próprio universo, não existem sistemas isolados.
} 
José Alberto da Costa Machado, Norbert Fenzl

ambiente relevante persiste e se alarga, ele é obrigado a mudar sua estrutura e essa evolução é chamada de auto-organização; se a mudança ambiental ganha grandes proporções, o sistema é forçado a fazer grandes mudanças estruturais e essa evolução é chamada de auto-reprodução. Nos dois primeiros processos, a evolução ocorre para proteger a integridade do sistema, mantendo a mesma identidade. No terceiro, ela se dá também para proteger a integridade mas com mudança de identidade (BOSSEL, 1996:3-11).

Evolução, em um sistema, não implica movimentos no rumo ou na direção de um "estado melhor"; significa, apenas, tornar a estrutura e o comportamento mais adequados para lidar com as novas condições ambientais. Entretanto, esse rumo também pode ser direcionado, para atender os "interesses" de quem o opera. Disso vem a idéia de desenvolvimento, isto é, direcionamento do sistema para um estado-alvo desejado, por exemplo, o estado-alvo "sustentado". Se nenhum direcionamento for feito, então funcionará o automatismo de suas dinâmicas implícitas, conduzindo o sistema à evolução pelo processo cego da tentativa e erro, em busca apenas de reproduzir-se, mesmo que, às vezes, ao custo de sua própria identidade.

Em razão da não-linearidade do comportamento de um sistema aberto, seu estado futuro só pode ser visto como probabilidade, que será tanto menos factível quanto maior for a quantidade de interrelações entre os componentes que o integram. Embora não seja possível prever seus estados futuros, é possível determinar o seu espaço de acessibilidade, isto é, o espaço no qual se pode assegurar que o sistema continuará mantendo sua integridade. Dentro desse espaço de acessibilidade, o sistema movimenta-se e, a cada fase evolutiva, sua estrutura ocupa uma região desse espaço, conhecida por espaço de fase.

Um estado qualquer de um sistema é uma situação irreversível no seu processo evolutivo. Entretanto, enquanto as configurações modeladoras de sua coerência, estrutura e identidade permanecerem estáveis, diz-se que ele se encontra em estado estacionário e que possui coerência estrutural, isto é, que existe correspondência lógica entre os componentes que garantem a organização de sua estrutura. Essa coerência é garantida pela resiliência do sistema, isto é, a capacidade de absorver interferências provindas do seu espaço externo, voltando para seu estado estacionário.

Um sistema, ao surgir, configura-se a partir de características que recebe como herança compulsória do ambiente onde surgiu. Por isso, sua evolução ocorre condicionada por um certo determinismo que limi- 
ta sua liberdade 19 na aquisição de novas características. Assim, a atualidade de um sistema é a configuração resultante de sua liberdade atuando em contraposição à realidade que lhe é imposta através de condicionantes herdadas e determinadas pela sua evolução.

Visto da dimensão microscópica para a macroscópica, um sistema é um foco de autonomia, imerso em um mar de indeterminações, pois que ele produz livremente sua atualidade, mas balizado por condicionantes desconhecidas de sua realidade. Enquanto ele se mantiver aderente a essas condicionantes, ele continuará existindo. Portanto, é necessário que seu comportamento e seu processo evolutivo estejam sempre consentâneos com essas circunstâncias impostas pelo seu ambiente relevante.

\subsection{Sustentabilidade de sistemas abertos}

Os sistemas emergem, crescem, assumem um estado estacionário, evoluem, assumem novos estados estacionários e, quando não conseguem sustentar esse estado, nem se impor evolução, morrem. Podese sintetizar esse ciclo da seguinte forma: (i) para garantir a reprodução do seu metabolismo energético-material, o sistema importa matéria e energia do seu ambiente relevante, o campo de interação; (ii) para que essa importação possa ocorrer, o sistema atua sobre seu ambiente relevante a fim de conformá-lo com suas necessidades; (iii) ao atuar para configurar esse ambiente e para importar matéria e energia, o sistema "importa" sinais de mudanças no ambiente, o que o obriga a reagir por meio de ajustes em seus parâmetros de funcionamento ou de mudanças estruturais; (iv) a energia necessária para essa permanente readaptação comportamental e estrutural é a entropia do sistema, que, se excessiva, inviabiliza sua existência.

Por isso, a sustentabilidade de um sistema aberto, do ponto de vista de sua atuação ${ }^{20}$, depende da natureza do seu metabolismo energético-material, isto é, de seu modo de reprodução: se este é ou não é sustentável. A qualidade desse metabolismo energético-material revela-se por efeitos observáveis, no ambiente relevante, na coerência estrutural e nos elementos internos do sistema. Esses efeitos precisam ser percebidos pelo sistema, para que ele possa ajustar seu metabolismo. Essa percepção dá-se por meio de certas propriedades básicas que, como visto antes, são herdadas do ambiente onde surge e funcionam, para ele, como fatores de orientação (os "orientadores") a sinalizar, permanentemente, seu grau de aderência ao ambiente. Em relação a esses

\footnotetext{
${ }^{19}$ Na literatura sobre sistemas sociais é comum associar-se esse conceito ao de contingência, que é a característica atribuída aos sistemas de ser o que são por terem tido a liberdade de escolher entre diversos cursos de ação que eram igualmente possíveis o escolhido não sendo, necessariamente, obrigatório.

${ }^{20}$ Há mutações ambientais que surgem autonomamente no ambiente e que também afetam a sustentabilidade do sistema.
} 
José Alberto da Costa Machado, Norbert Fenzl

orientadores, o sistema tem que ajustar seus "interesses" (seu metabolismo energético-material), para poder manter-se sustentável. BOSSEL (1996:4-5) detalha esse enfoque e propõe os seguintes orientadores:

- existência: assegura que o sistema pode sobreviver no estado normal ${ }^{21}$ do ambiente;

- eficácia: assegura que o sistema, a longo prazo, é efetivo em sua manutenção, mesmo em face da escassez de recursos ${ }^{22}$ do ambiente e em exercer influência sobre ele com esse fim;

- liberdade de ação: assegura que o sistema tem habilidade para lidar, de várias maneiras, com a variedade³ de situações apresentadas pelo ambiente;

- segurança: assegura que o sistema é capaz de proteger-se dos efeitos nocivos oriundos da inconstância ${ }^{24}$ do ambiente, mesmo em face de flutuações distantes do seu estado normal;

- adaptabilidade: assegura que o sistema tem a capacidade de adaptar seus parâmetros ou estrutura às mutações ${ }^{25}$ no estado normal do ambiente;

- coexistência: assegura que o sistema é capaz de "conviver" com o comportamento de outros sistemas ${ }^{26}$ presentes em seu ambiente;

- necessidades psicológicas: assegura que o sistema é capaz de buscar satisfações e evitar frustrações, dores e incômodos dos seus componentes (indivíduos) - esse orientador é específico dos sistemas sociais.

Tais orientadores, quando satisfeitos, indicam que o sistema é sustentável, isto é, que o modo de reprodução do seu metabolismo energético-material tem sustentabilidade.

\subsection{Relação Sociedade-Ambiente vista como um Sistema}

A partir da teoria de sistemas e em face das propostas de FISCHER-KOWALSKI (1997) e de BOSSEL (1996:4.8-4.15)27, é possível

\footnotetext{
${ }^{21}$ Estado normal: existe, em todo ambiente, um estado normal que varia apenas em torno de uma certa faixa.

${ }^{22}$ Escassez de recursos: o ambiente não dispõe, de forma contínua e suficiente, e em todos os seus espaços, de recursos necessários à sobrevivência do sistema.

${ }^{23}$ Variedade: no ambiente aparecem, desaparecem e permanecem, constantemente, muitos processos e variáveis ambientais distintos.

${ }^{24}$ Inconstância: o estado normal do ambiente pode, ocasionalmente, flutuar aleatoriamente levando o sistema para longe do estado estacionário.

${ }^{25}$ Mutação: ao longo do tempo, o estado normal do ambiente pode mudar abrupta ou gradualmente, para outro diferente estado normal.

${ }^{26}$ Presença de outros sistemas: cada sistema que compartilha um ambiente pode introduzir mudanças no ambiente de outro sistema.

${ }^{27}$ As vantagens e desvantagens das duas propostas, incluindo os detalhes do modelo aqui proposto, encontram-se em MACHADO, 1999:32-36.
} 
compreender a relação Sociedade-Ambiente, a partir do modelo apresentado na Figura 1.

Partindo-se desse modelo (Figura 1), a relação entre a Natureza (biosfera e base abiótica de recursos) e as Sociedades Humanas (os homens e suas culturas) dar-se-ia pela interação de quatro componentes fundamentais: o Sistema Ambiente (parte da natureza terrestre que é relevante para ação humana sob uma determinada cultura), o Sistema Infra-Estrutura ${ }^{28}$ (conjunto de aparatos que possibilitam a apropriação dos recursos ambientais), as Pessoas Humanas 29 e a Cultu$\mathrm{ra}^{30}$. Esses componentes desempenhariam diferentes papéis. (i) O Sistema Ambiente, contendo os elementos materiais da realidade e regido por complexas interações biogeoquímicas, desempenha a função de fonte de recursos energéticos-materiais, de depósito dos rejeitos e de suporte à vida. (ii) A Cultura, um sistema simbólico, desempenha o papel de memória dos valores e crenças acumuladas pelo processo civilizatório, por meio de registros escritos, de aparatos infra-estruturais, de tradições e das operações correntes de comunicação dos subsistemas que a compõem, a saber: Sistema Econômico, Sistema de Governança, Sistema de Suporte à Sociedade e Sistema de Suporte ao Indivíduo. (iii) As Pessoas Humanas, enquanto sistemas psíquicos, atuam como parte da memória da Cultura e como seu ambiente de interação, introduzindo nela, mediante operações de comunicação, a representação das necessidades surgidas da experiência sentida na interação com o Sistema Ambiente. Enquanto organismos, ou quando em condições primitivas, as Pessoas Humanas podem ser analisadas como simples integrantes do Sistema Ambiente que, sentindo por experiência as mudanças no Ambiente, aplicam trabalho para adequá-lo aos interesses dos seus metabolismos energético-materiais. Mas, organizados socialmente, esses metabolismos passam a ser mediados por visões culturais, por isso, interagem com o Sistema Ambiente não mais para satisfazer apenas necessidades de manutenção ou reprodução, mas como agentes de fun-

\footnotetext{
${ }^{28}$ Como artefato material, o Sistema Infra-Estrutura participa do Ambiente como os demais elementos materiais. Mas, porque construído com lógica culturalmente configurada, ele participa das sociedades humanas e, uma vez encaixado no Ambiente, passa a constituir, juntamente com as Pessoas Humanas, o entorno da Cultura (e não como parte constituinte), em relação à qual atua e é por ela afetado.

${ }^{29}$ Pessoas Humanas são aqui consideradas sob o conceito de LUHMANN (1998:235-254), isto é, como a junção de um organismo, a parte material, com um sistema psíquico, a parte virtual. Como organismo, as pessoas participam do Ambiente como as demais espécies. Como sistema psíquico, elas participam das sociedades humanas como o entorno da cultura (e não como partes constituintes), em relação à qual atuam e são por ela afetados.

${ }^{30}$ Cultura, neste contexto, expressa uma das acepções discutidas em NUNES (1997:532), a acepção social, isto é, a herança transmitida de geração a geração, comportando moldes de pensamento, padrões de gosto e normas de proceder, que tem existência independente dos indivíduos - seus usufrutuários - e que a eles se impõe como provinda de uma instância exterior. Essa idéia de cultura, aqui, é utilizada para expressar o sistema resultante da interação entre os diversos sistemas sociais que formam uma específica sociedade. A natureza desses sistemas, constituídos exclusivamente por comunicações, foi detalhadamente examinada por LUHMANN (1998).
} 
José Alberto da Costa Machado, Norbert Fenzl

ções físicas da Cultura, em particular do seu Sistema Econômico. (iv) O Sistema Infra-Estrutura, que emerge com o aumento e interconexão dos aparatos técnicos (estradas, hidrelétricas, cidades, etc), enquanto artefato material socialmente configurado, atua como parte da memória da Cultura e como seu ambiente de interação, fazendo repercutir nela, por meio do Sistema Econômico e do Sistema de Suporte à Sociedade, a experiência registrada em relação às mudanças ocorridas no Sistema Ambiente. Na parte material, ele pode ser analisado como simples integrante do Sistema Ambiente, mas, porque construído para atender necessidades culturalmente configuradas, participa do Sistema Ambiente como agente de funções físicas, isto é, de trabalho, da Cultura, por meio do Sistema Econômico e do Sistema de Governança na ação colonizadora do Sistema Ambiente.

Figura 1 - Modelo de interação Sociedade-Ambiente

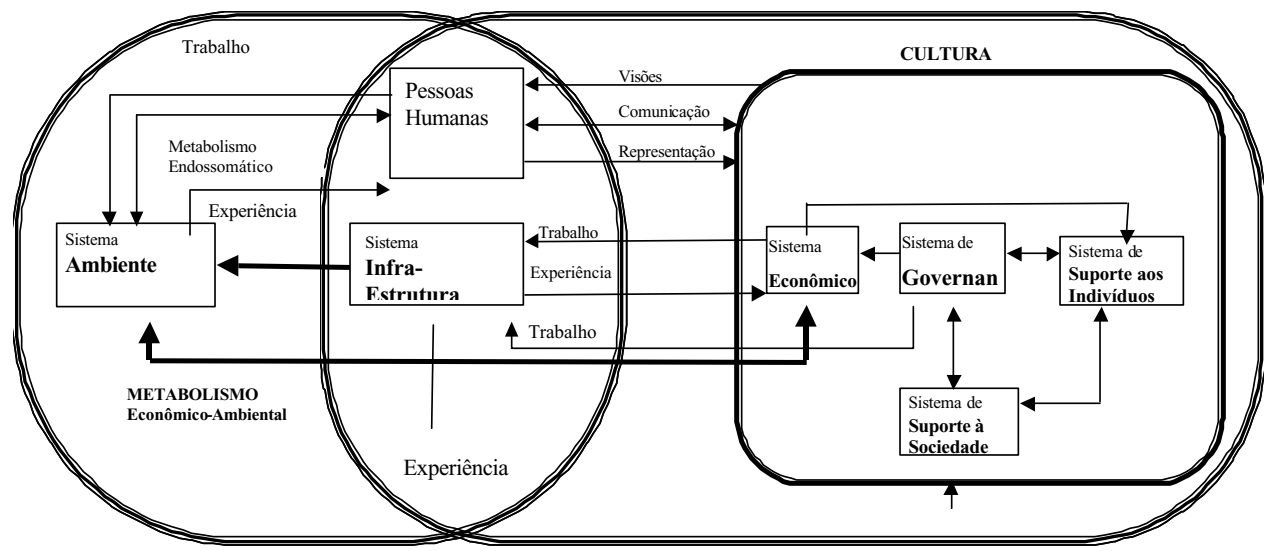

Fonte: Construído a partir de acréscimos feitos em FISCHER-KOWALSKI (1997:8) e BOSSEL (1996:4.14).

A conjunção de Cultura, Pessoas Humanas e Sistema Infra-Estrutura constitui a Sociedade 31 e o Sistema Ambiente representa a sua base energético-material, isto é, seu ambiente relevante. Em condições

\footnotetext{
${ }^{31}$ A partir deste ponto o conceito de Sociedade, neste trabalho, passa a remeter à conjunção de Cultura (formada por um conjunto de sistemas sociais, tais como o econômico, governo, etc), de Pessoas Humanas (em sua parte psíquica) e do Sistema Infra-Estrutura (em sua lógica configuradora). Apesar de funcionalmente interdependentes, a relação descrita não pode ser vista como instrumental. A Cultura não pode controlar totalmente as Pessoas Humanas porque estas, além de seguirem uma outra lógica enquanto espécies, são também sistemas psíquicos autônomos e interagem com a Cultura como parte do seu entorno e não como suas partes constituintes. Também não pode controlar totalmente o Sistema InfraEstrutura porque este passa a ser configurado, também, pelo Sistema Ambiente e, além disso, possui lógica própria e interage com a Cultura como parte do seu entorno e não como seu elemento constituinte. As Pessoas Humanas interagem com a Cultura de forma individual, mas todas simultaneamente, por isso não é possível qualquer pretensão de hegemonia ou controle de pessoas ou grupos de pessoas sobre a Cultura. O Sistema Infra-Estrutura certamente baliza as dinâmicas da Cultura, seja como sinalizador das mudanças ambientais, seja como vetor de padrões condicionadores, mas a Cultura tem lógica própria que só muda quando as demandas nesse sentido são amplas e duradouras, por isso o Sistema InfraEstrutura não pode mudar, por si só, os padrões Cultura.
} 
primitivas, as Pessoas Humanas desenvolvem com o Sistema Ambiente um metabolismo endossomático ${ }^{32}$. Organizadas em Sociedade, suas demandas em relação ao Sistema Ambiente passam a ser culturalmente configuradas. Parte dessas demandas são mediadas pelo Sistema Econômico, desenvolvendo-se, entre ambos, um particular metabolismo energético-material - o Metabolismo Econômico-Ambiental (MEA), diferente tanto do metabolismo endossomático ${ }^{33}$, quanto do metabolismo energético-material da Sociedade total ${ }^{34}$. No interesse do MEA, e utilizando-se do Sistema Infra-Estrutura, o Sistema Econômico desenvolve um tipo de Colonização do Sistema Ambiente. Essa colonização é potencializada pelos interesses do Sistema de Governança para atender demandas vindas das interações com os Sistemas de Suporte ao Indivíduo e de Suporte à Sociedade.

O conjunto das interações Sociedade-Ambiente, tal como descritas, pode ser visto como um sistema - o Sistema Sócio-Ambiental (SSA). Como todo sistema aberto, possui um metabolismo energético-material, cuja natureza pode ser avaliada por meio do comportamento dos seus subsistemas. O Metabolismo Econômico-Ambiental (MEA) e a Colonização seriam dinâmicas concretas por meio das quais se torna possível o acesso empírico à parte do metabolismo energético-material (aquela mediada pelo Sistema econômico) do sistema total, e o Material Flow Analysis (MFA) seria a metodologia para a operacionalização desse acesso.

\subsection{A sustentabilidade da relação Sociedade-Ambiente}

O desenvolvimento sustentável do Sistema Sócio-Ambiental (SSA) é o grande desafio dos dias presentes. Como visto antes, a questão central de um desenvolvimento assim reside no modo de reprodução do metabolismo energético-material ${ }^{35}$ do sistema total. Esse metabolismo reflete-se no comportamento de todos os subsistemas integrantes e pode

\footnotetext{
${ }^{32}$ ALIER (1996:3) define-o como o consumo energético-material dos humanos que visa a satisfação de um metabolismo apenas de subsistência.

${ }^{33}$ Como será visto mais adiante, o MEA não é apenas a soma do metabolismo endossomático das Pessoas Humanas. O Sistema Econômico tem uma lógica que o faz, de forma contínua e crescente, cada vez mais consumidor de matéria e energia, independentemente do quanto é apropriado diretamente pelas Pessoas Humanas.

${ }^{34}$ O MEA representa apenas parte do metabolismo energético-material da Sociedade em relação ao Ambiente, porque parte deste não se dá via Sistema Econômico. Supõe-se, entretanto, que, sendo este o principal instrumento de atendimento às necessidades energético-materiais da Sociedade, ele represente sua porção mais significativa.

${ }^{35}$ Graças a essa idéia, pode-se identificar uma causa empírica e concretamente localizada para a insustentabilidade, independentemente de qualquer pressuposto ideológico, filosófico ou cultural. Conhecer as razões que levam esse metabolismo a ser de uma qualidade ou de outra passa a ser um outro foco de estudo, obviamente fundamental para qualquer expectativa em relação à sua mudança consciente e temporânea. Entretanto, a identificação de uma dinâmica concreta para acessar a sustentabilidade do sistema representa um passo fundamental para dar unidade e sinergia às iniciativas em busca de um padrão de desenvolvimento mais sustentável, afinal, como constatou BRUSEKE (1996:298), a busca de uma saída, desta vez, não é mais uma mera tensão entre alternativas culturais, filosóficas ou éticas, e sim uma questão de emergência.
} 


\section{José Alberto da Costa Machado, Norbert Fenzl}

ter sua natureza examinada através de vários pontos de acesso, como, por exemplo, as patologias sociais, as desestruturações institucionais, as desigualdades na qualidade de vida, etc. Como já descrito, o Metabolismo Econômico-Ambiental (MEA) e a Colonização são as dinâmicas concretas que permitem o acesso empírico à parte do metabolismo energético-material do sistema total, relacionadas com a apropriação, o uso e o despejo de recursos energético-materiais feitos pela Sociedade por intermédio do Sistema Econômico.

A relação dessas duas dinâmicas com a insustentabilidade do atual padrão de desenvolvimento pode ser sintetizada como segue. (i) O Sistema Econômico atua sobre o Sistema Ambiente por meio de suas dinâmicas relacionadas com a obtenção, o uso e a deposição de recursos energético-materiais. Isso representa o Metabolismo EconômicoAmbiental. (ii) O Sistema Ambiente recebe os impactos da atuação do Sistema Econômico e reage modificando-se. Essas modificações são sinalizadas ao Sistema Econômico por meio de escassez de recursos naturais, comprometimento de ecossistemas e mudanças mais globais. (iii) O Sistema Econômico, para suplantar esses efeitos, atua sobre o Sistema Infra-Estrutura, alargando-o ou adequando-o às novas necessidades. O Sistema Infra-Estrutura potencializa as ações do Sistema Econômico, mas interfere no Sistema Ambiente, por meio de sua Colonização, contínua e acumulada. O Sistema Ambiente muda cada vez mais, distanciando-se do seu modo normal de funcionamento. (iv) Enquanto essas mudanças não são percebidas como danosas pelas Pessoas Humanas, a Cultura não reorganiza suas crenças e valores. Não alterando suas crenças e valores, a Cultura reitera o modo de reprodução do Metabolismo Econômico-Ambiental, mesmo que surjam patologias nos outros subsistemas.

Nas sociedades de caçadores e coletores, as Pessoas Humanas desenvolviam com o Sistema Ambiente uma interação quase exclusivamente biológica ${ }^{36}$. Porque este pouco se modificava, a Cultura era pouco demandada para ensejar mudanças no comportamento das Pessoas Humanas. Da revolução agrícola do neolítico até o presente, e em especial com as transformações culturais que deram origem à Ciência e Tecnologia da modernidade 37 , as sociedades passaram a depender sempre cada vez mais de artefatos técnicos (infra-estrutura construída e instrumentos) e de artefatos biológicos (animais e plantas domestica-

\footnotetext{
${ }^{36}$ Essa necessidade mínima já foi tratada anteriormente como "consumo endossomático". O adicional a esse mínimo tem sido referido como "consumo exossomático" (ALIER, 1996:3).

${ }^{37}$ Na parte relativa às Conclusões deste trabalho, há considerações sobre a influência da CGT moderna no crescimento incontrolável do MEA e da Colonização.
} 
dos e modificados geneticamente pelo homem). Em face de uma cultura de desperdício, o consumo energético-material transformou-se em perdulário, excedendo em muito a soma das necessidades individuais. Ademais a sociedade tem agora que investir muitos recursos na construção e na manutenção do seu estoque de artefatos (Sistema Infra-Estrutura).

Em razão disso torna-se necessário trazer à tona o peso do modo de reprodução do Sistema Econômico e do Sistema Infra-Estrutura em relação ao Sistema Ambiente, para que as Pessoas Humanas, na condição de sistemas psíquicos, tomem consciência dos riscos que correm pelas mutações do Ambiente e possam atuar no sentido de alterar as crenças e valores de sua Cultura.

Assim, considerando todas as dimensões sob as quais o metabolismo energético-material do Sistema Sócio-Ambiental (SSA) pode ser analisado e, aplicando o enfoque dos orientadores descrito na seção 1.2, podese considerar que seu desenvolvimento é sustentável ${ }^{38}$ enquanto ele for capaz de: (i) manter sua integridade frente às mutações ambientais oriundas das transformações globais (dimensão física); (ii) obter matéria e energia para sustentar seu metabolismo energético-material em face da escassez de recursos naturais (dimensão material); (iii) manter os ecossistemas do seu Ambiente com capacidade de reintegrar rejeitos aos seus ciclos próprios sem degradar-se face ao contínuo comprometimento desses ecossistemas (dimensão ecológica); (iv) controlar os efeitos das contradições e disputas resultantes das desigualdades entre seus componentes e que causam patologias sociais (dimensão social); (V) fomentar satisfações e minimizar frustrações dos indivíduos que o integram, em face de aspirações não atendidas (dimensão psicológica); (vi) manter a diversidade de modos de vida para possibilitar escolhas futuras, em face da globalização de crenças e valores (dimensão cultural); (vii) impor-se limites por consciência e respeito altruísta em relação ao seu Ambiente em face da compulsão por apropriação de recursos (dimensão ética).

Um desenvolvimento assim requer o estabelecimento de um rumo, conscientemente escolhido como o "fim maior" a ser buscado. Todas as dinâmicas presentes no funcionamento do sistema devem ser aderentes a esse "fim maior". Deixado sem esse balizamento, o sistema desenvolver-se-á, mas configurado pelos automatismos implícitos e pelos processos cegos em busca de adaptação, conforme a conceituação adotada para a evolução dos sistemas, na seção 1.1. Essa parece ter sido a opção trilhada até agora, a qual trouxe a sociedade aos impasses em relação à sustentabilidade do seu desenvolvimento.

\footnotetext{
${ }^{38}$ A definição aqui estabelecida distancia-se da maioria daquelas que transitam na literatura, porque não incorpora substratos normativos, ideológicos ou culturais. Apenas considera, de forma fundamentada, aspectos empíricos para mensuração da sustentabilidade do metabolismo energético-material do sistema.
} 
José Alberto da Costa Machado, Norbert Fenzl

\subsection{Referencial para indicadores de sustentabilidade}

Um sistema de indicadores ${ }^{39}$ para visualizar a sustentabilidade do Sistema Sócio-Ambiental (SSA), antes descrito, deveria fornecer informações essenciais sobre: (i) o estado e a viabilidade de cada subsistema; (ii) o estado e a viabilidade do sistema total; (iii) a posição de cada subsistema e do sistema total frente aos objetivos do desenvolvimento sustentável. Indicadores específicos devem ser encontrados para cada subsistema e também para o sistema total, os quais representariam pontos de acesso empírico ao metabolismo energético-material do Sistema SócioAmbiental como um todo. BOSSEL (1996:4-3) apresenta uma relação de 220 indicadores divididos em categorias, que representam focos específicos para esse acesso empírico ao metabolismo, a saber: i ndicadores normativos e éticos, indicadores psicológicos, indicadores de qualificação, indicadores organizacionais, indicadores de condições de vida, indicadores de bem-estar e condições sociais, indicadores de recursos materiais, indicadores financeiros e econômicos, indicadores de dependência e indicadores de carga ambiental. Apresenta também tabelas mostrando como esses indicadores se interconectam e se influenciam mutuamente, de modo a possibilitar a adequada aferição da satisfação de cada orientador (vide seção 1.4) nos vários sistemas setoriais e no sistema total.

O Material Flow Analysis (MFA), como metodologia para acessar o Metabolismo Econômico-Ambiental e a Colonização, fornece base para a produção da totalidade dos Indicadores de Recursos Materiais e dos Indicadores de Carga Ambiental. A parte empírica do trabalho ocuparse-á de indicadores sobre demanda material do Sistema Econômico.

\section{Material Flow Analisys (MFA) e Metabolismo Econômico- Ambiental (MEA)}

\subsection{O encaixe dos conceitos}

Tradicionalmente, a economia mede a eficiência do MEA por meio de valores monetários que o virtualizam e seleciona componentes usa-

\footnotetext{
${ }^{39}$ As propostas de indicadores de sustentabilidade do desenvolvimento (SPANGENBERG e SCHMIDT-BLEEK, 1997; SPANGENBERG e BONNIOTO, 1997; SPANGENBERG, 1996a e 1996b; OECD, 1993; WORLD BANK, 1995; UNDP, 1996; SECTMA, 1997 CONSTANZA et al., 1997, etc), além da diversidade em seus fundamentos, trazem dois problemas centrais: ou enfatizam as relações com o Ambiente ou setorizam seus focos sem integrá-los em uma visão global. Uma tentativa competente de fundir fundamentos causalístas efuncionalistas, feita por BRUYN e DRUNEN (1999:6), continua priorizando o foco da interação com o Ambiente e não destaca a interdependência entre os indicadores. Uma outra proposta que parece suplantar essas questões foi feita por BOSSEL (1996:4-3). Com base no enfoque de que cada sistema deve possuir orientadores capazes de sinalizar seu grau de aderência ao ambiente no qual está imerso, é de supor-se que os indicadores de sua sustentabilidade representem as informações necessárias para avaliar se seus orientadores estão e continuarão sendo atendidos, se o sistema é e continuará sendo sustentável em seu ambiente. Para esse autor, indicadores de sistemas devem possuir dois requisitos: fornecer as informações vitais sobre seu estado atual e fornecer as informações necessárias para a intervenção em seu comportamento. Isso significa que os indicadores são determinados a partir dos "interesses" do próprio sistema e pelos interesses, necessidades e objetivos de quem o opera.
} 
dos na medição dessa eficiência. Assim, de um lado está a base real do MEA repousando sobre fluxos concretos de matéria e energia (Figura 2), de outro lado está a base monetária do Sistema Econômico que mede a eficiência MEA apenas pela circulação monetária representativa dos processos de produção-circulação-consumo.

Figura 2 - Metabolismo Econômico-Ambiental (MEA)

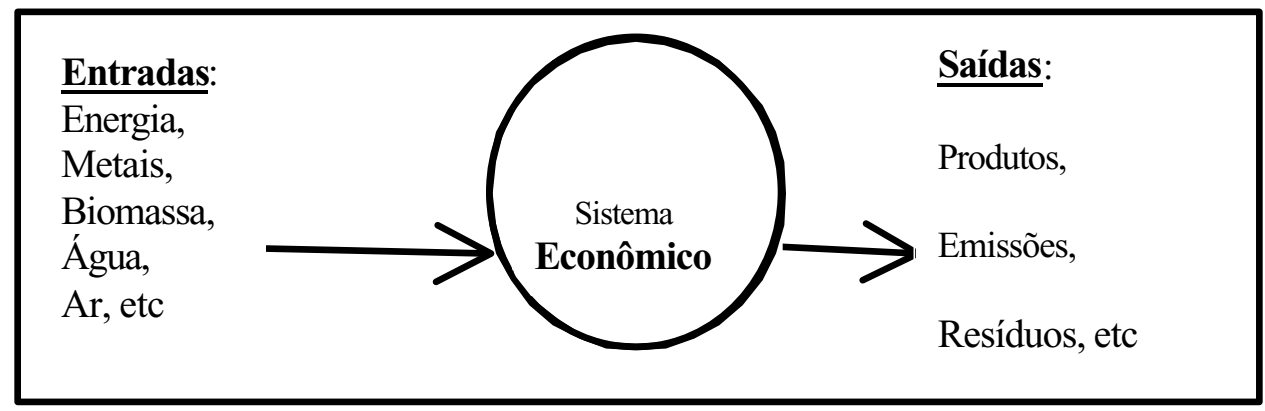

Fonte: FISCHER-KOWALSKI e HABERL (1994:4).

Os problemas passíveis de afetar o funcionamento desse MEA são relacionados com as suas "entradas" e "saídas" energético- materiais, bem como com a extensão do seu "tamanho" em relação ao Ambiente.

Com referência às entradas, os problemas surgem quando as fontes de recursos naturais que sustentam o MEA ficam comprometidas. Essa escassez de recursos naturais pode ocorrer, tanto pelo esgotamento das reservas de recursos não renováveis quanto pelo uso de recursos renováveis acima de sua taxa de recomposição. As Sociedades geralmente reagem por meio da migração, da redução da procriação, da mudança de hábitos alimentares, da alteração nos modos de produção, da guerra, etc.

Com referência às saídas, os problemas podem ocorrer na medida em que os resíduos produzidos pela Sociedade não possam ser absorvidos de maneira natural pelo Ambiente. Enquanto esse tipo de problema esteve confinado em espaços localizados, a solução veio sempre por meio de medidas restritivas. Entretanto, com o advento do industrialismo, o aumento da produção de resíduos não-recicláveis transformou-se em fonte de ameaças. Uma das razões, mas não a única, relaciona-se com a utilização de matéria-prima (petróleo, minério, carvão, etc.) extraída não mais do ciclo biológico corrente na biosfera, mas de reservatórios subterrâneos fósseis. O uso maciço desse tipo de matéria-prima gera resíduos de difícil absorção e que, em razão do volume, interferem no funcionamento tanto de ecossistemas localizados quanto nos grandes sistemas que regulam os ciclos vitais planetários. Um exemplo disso é o 
José Alberto da Costa Machado, Norbert Fenzl

dióxido de carbono com sua conhecida contribuição tanto para a poluição atmosférica de grandes centros industriais quanto para o chamado "efeito estufa", de graves conseqüências em relação às mudanças climáticas globais.

Se essas saídas se tornam mórbidas em relação a ecossistemas localizados, em principio, os problemas causados são similares aos do passado. Entretanto, há um fator novo na atualidade, que é o tamanho desse MEA. Diferentemente do que ocorreu às Sociedades do passado, que eram sistemas abertos em relação aos seus Ambientes, o sistema cultural atual assumiu uma escala global. Nessas circunstâncias, o ambiente natural como um todo passou a ser parte de um megassistema socioambiental de ciclo fechado. Embora as Sociedades não tenham ainda efetivado dominação presencial em todo o ambiente natural, há bastante evidência de que os efeitos das atividades do seu Sistema Econômico estendem-se por um campo muito mais amplo do que os seus contornos físico-estruturais, enfoque que a Teoria de Sistema associa ao conceito de campo de interação.

Das considerações acima, duas conseqüências surgem em relação às condições de sustentabilidade do MEA. A primeira refere-se à sinergia surgida da agregação entre os efeitos dessas saídas quando o tamanho do MEA se globaliza. Nessa situação os ciclos biogeoquímicos que garantem a habitabilidade da Terra podem transformar-se e induzir mudanças globais. A segunda refere-se à amplitude espacial da influência dessas saídas quando o tamanho do MEA se globaliza. Ele passa, então, a assimilar a matéria e energia degradadas e depositadas no Ambiente, isto é, seu depósito de rejeitos é, ao mesmo tempo, sua fonte de recursos. Essa situação causa comprometimento dos ecossistemas, e, porque esse ambiente deixa de ser algo externo à sociedade, as interferências e deposições nocivas realizadas em relação a ele, passam a atingir a própria sociedade.

O termo Colonização pode ser entendido como o conjunto de atividades que a Sociedade desenvolve, por meio do Sistema Infra-Estrutura, de forma deliberada, visando manter e ampliar as atividades do seu MEA. Assim, ela transforma o ambiente natural do planeta, reconfigura-o e adapta-o a esse objetivo, produzindo interferências no seu funcionamento. Dessa forma, florestas são transformadas em espaços agrícolas, em campos de criação, em rodovias e em cidades; espécies animais e vegetais são alteradas geneticamente para se tornarem mais resistentes a doenças, mais produtoras de proteínas e mais produtoras de massa; e rios são transformados em grandes lagos e represados para a geração de energia hidrelétrica (FISCHER-KOWALSKI e HABERL, 1993:19). 
Essas atividades são desenvolvidas pelo Sistema Infra-Estrutura, por isso não são exatamente parte do MEA, entretanto, porque destinadas a potencializar, ao máximo, aquilo que a Sistema Econômico pode extrair do Ambiente, elas acabam afetando-o em seu equilíbrio e potencializando os problemas relacionados com as entradas, as saídas e o tamanho do MEA.

Com base nos dois conceitos, a história da sustentabilidade da relação Sociedade-Ambiente pode ser analisada a partir da forma pela qual a Sociedade tem organizado o seu MEA e colonizado o ambiente natural ${ }^{40}$.

\subsection{O objeto da medição}

Atualmente, não há ainda padrões consolidados internacionalmente em torno do MFA. Este trabalho apóia-se em certas diretrizes emergentes entre os pesquisadores e nas ampliações propiciadas pela referência teórico-metodológica que o sustenta. Os dados referentes ao Brasil, coletados especificamente para o trabalho, seguem as diretrizes metodológicas completamente descritas nesta seção. Os dados comparativos (referentes aos EUA, à Alemanha, ao Japão e à Holanda) foram coletados de fontes internacionais e, embora baseados na mesma matriz metodológica, necessitaram ajustes, os quais serão apresentados mais adiante.

Como visto antes, o Metabolismo Econômico-Ambiental (MEA) e a Colonização expressam-se por efeitos concretos sobre o Ambiente. Um está associado à obtenção, ao uso e à deposição de recursos energéticomateriais e o outro à ocupação dos espaços ambientais com artefatos e estruturas destinados a potencializar as ações do Sistema Econômico. A parte empírica deste trabalho ocupa-se com o MEA e, de forma mais específica, com a parte dele relacionada às entradas, conforme modelo da Figura 2. De uma forma mais genérica, esse modelo pode ser apresentado como abaixo (Figura 3):

Figura 3 - Principais fluxos do Metabolismo Econômico Ambiental

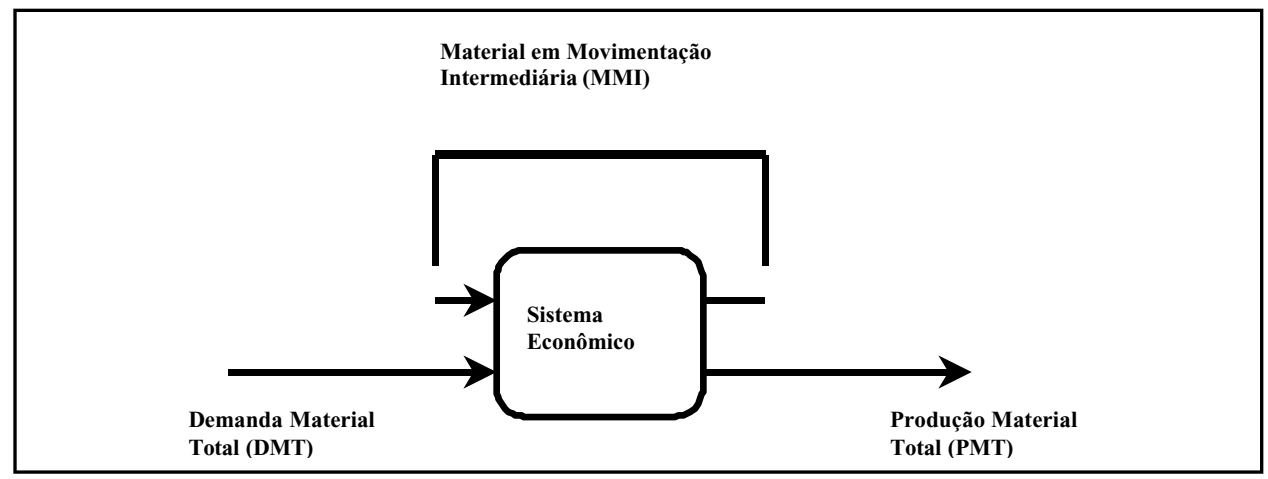

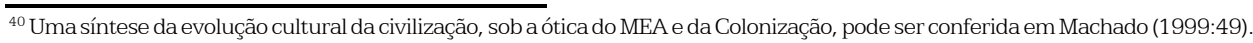


José Alberto da Costa Machado, Norbert Fenzl

(MEA)

A Demanda Material Total (DMT) representa a totalidade de todos os recursos que o Sistema Econômico retira do Ambiente para sustentar seu MEA. O Material em Movimentação Intermediária (MMI) representa a totalidade dos recursos que ficam em movimento no interior da economia, passando de um setor para outro até ganhar uma destinação final. A Produção Material Total (PMT) representa a totalidade dos recursos que receberam forma final dada pelo Sistema Econômico e que são expressáveis pelos produtos manufaturados (destinados ao consumo, investimento, exportação e estocagem), emissões (substâncias eliminadas do processo produtivo) e resíduos (lixo e sucata). Emissões, resíduos e uma parte dos produtos manufaturados (fertilizantes, pesticidas, etc) voltam ao Ambiente; a outra parte dos produtos manufaturados (construções, estradas, etc) vão representar a medida da Colonização desenvolvida pelo Sistema Infra-estrutura. Segundo os princípios dos Sistemas de Contabilidades Nacionais ${ }^{41}$, a seguinte equação também deve ser verdade para os fluxos materiais ${ }^{42}$ :

$\mathrm{DMT}=\mathrm{MMI}+\mathrm{PMT}$

O exame de cada um dos agregados dessa equação propiciaria o completo entendimento do MEA. O presente trabalho focaliza a DMT, que pode ser entendida como a soma dos fluxos de três agregados materiais (Figura 4).

- Recursos Naturais Livres: trata-se daqueles recursos que, mesmo apropriados pelos processos econômicos, não são passíveis de ter seus estoques controlados e nem de se tornar propriedade. Por essa razão não possuem preço e nem peso monetário sobre a eficiência da economia. Exemplos principais são a água e o ar. Por causa da dificuldade em mensurá-los e das diferenças culturais nos seus padrões de uso, esse fluxo não será considerado neste trabalho ${ }^{43}$.

- Demanda Doméstica Total (DDT): trata-se da totalidade dos

\footnotetext{
${ }^{41}$ As contabilidades nacionais consideram que, em termos monetários, o valor bruto de toda a produção do Sistema Econômico é igual à soma do valor adicionado à economia (o Produto Interno Bruto) com o valor da produção absorvido pelos processos geradores de bens intermediários (o Consumo Intermediário). Isso significa que Valor Bruto da Produção = Produto Interno Bruto + Consumo Intermediário.

${ }^{42}$ Essa premissa tem sido tratada na literatura como Lei de Conservação de Massas nos processos socioeconômicos (FISCHERKOWALSKI, 1999b:7).

${ }^{43}$ Entretanto, a água mineral que se transforma em utilidade será contada.
} 
recursos materiais, de origem nacional, utilizados pelos processos econômicos para a produção das utilidades ${ }^{44}$ demandadas pelo mercado. Isso significa que os recursos apropriados pelas populações para a subsistência (agricultural tillage), sem passar pelo mercado, não são demandas do Sistema Econômico. ${ }^{45}$ O ponto de contagem é o momento em que são retirados do Ambiente, pela primeira vez, pelo homem.

- Demanda Importada Total (DIT): trata-se da totalidade de materiais, de origem estrangeira, contados quando cruzam a fronteira do país e que são utilizados pelos processos econômicos nacionais para a produção das utilidades demandadas pelos mercados 46 .

Tanto a DDT quanto a DIT são formadas por duas partes. A primeira, a parte Reconhecida, refere-se à matéria contida, de forma direta, nas utilidades em que se convertem os recursos naturais saídos diretamente do Ambiente. Para o Sistema Econômico, esse é o fluxo que existe, isto é, que é reconhecido como real. Já dos desperdícios que ocorrem até que o recurso natural se transforme em utilidade ele não toma conhecimento. A segunda, a parte Ignorada ${ }^{47}$, refere-se aos materiais que são usados ou movimentados para que determinado recurso se transforme em utilidade, mas que não são incorporados às utilidades negociadas no mercado. Por exemplo, um minério é retirado da mina com impurezas e só uma parte transforma-se em utilidade; uma árvore é cortada e somente parte dela é transformada em toras, a matéria prima para as serrarias ${ }^{48}$.

Assim, os fluxos materiais básicos considerados neste trabalho, como componentes da DMT, são: Demanda Doméstica Reconhecida $(D D R)$, que é a somatória da DDR de todos os materiais; Demanda Doméstica Ignorada (DDI), que é a somatória da DDI de todos os materiais;

\footnotetext{
${ }^{44} \mathrm{O}$ termo utilidade está sendo empregado para designar todo ente que pode ser considerado um bem econômico, isto é, que tem valor monetário e que pode ser objeto de transação em mercado (a literatura trata-o, quase sempre, como commodity). Essas utilidades transitam no Sistema Econômico como Matéria-Prima, Semi-Acabados e Manufaturados, todos genericamente considerados mercadorias. Entretanto, como esse termo está mais associado a bens industrializados e, neste trabalho, a ênfase será para bens econômicos primários, optou-se por utilizar o termo utilidade. Então, de uma outra forma, utilidade seria o estágio em que o recurso natural recebe um valor econômico, isto é, passa a ser considerado Matéria-Prima ou Bem de Consumo in natura, ambos também passíveis de serem tratados como mercadorias.

${ }^{45}$ Trata-se de algo aproximado ao consumo endossomático definido em ALIER (1996:3).

${ }^{46}$ Em uma economia global, na qual os recursos naturais são extraídos em um país, transformados em mercadoria em outro e consumidos em um terceiro, esses fluxos possuem grande relevância porque revelam o quanto a opulência de certos países é função de custos ambientais em outros.

${ }^{47}$ São tratados como mochila ecológica ou fluxos ocultos. Obviamente, a pressão exercida pelos fluxos indiretos é diferente daquela exercida pelo fluxo que é diretamente absorvido pelo Sistema Econômico. Há várias possibilidades de classificar esses fluxos com o objetivo de atribuir-lhes pesos diferentes. ADRIAANSE et al. (1997:6) citam dois: grau de mobilidade e potencial de nocividade. Neste trabalho não está sendo feita nenhuma distinção quanto a isso.

${ }^{48}$ A parte ignorada da matéria demandada pelo Sistema Econômico não é contabilizada porque este não possui "sensores" capazes de internalizar os efeitos de sua existência. Ela ocorre, quase sempre, em atividades extrativas, agrosilviculturais e possui características próprias que serão especificadas quando forem apresentadas as diversas categorias de materiais.
} 
José Alberto da Costa Machado, Norbert Fenzl

Demanda Importada Reconhecida (DIR), que é a somatória da DIR de todos os materiais; Demanda Importada Ignorada (DII), que é a somatória da DII de todos os materiais.

Com base nesses quatro fluxos, dois outros podem ainda ser compostos: Demanda Reconhecida Total (DRT), que é a soma da DDR com a DIR e expressa a quantidade de matéria reconhecida pelo Sistema Econômico; Demanda Ignorada Total (DIgT), que é a soma da DDI com a DII e expressa a quantidade de matéria que, embora movimentada para a geração das utilidades negociadas no mercado, é ignorada pelo Sistema Econômico.

Parte da Demanda Doméstica Total é utilizada para a geração dos produtos exportados pela economia, os quais dão origem a um outro tipo de fluxo, a Demanda Exportada Total (DET) ${ }^{49}$, que demonstra o peso que o Ambiente de um país suporta para beneficiar outros países. A DET é composta por dois outros, a saber: a Demanda Exportada Reconhecida (DER), que se refere à totalidade de matéria embutida, de forma direta, nos produtos produzidos nacionalmente e exportados para outros países, sendo obtida pela soma da Demanda Exportada Reconhecida (DER) de cada material; a Demanda Exportada Ignorada (DEI), que se refere à totalidade de matéria que, embora movimentada para a geração dos produtos exportados, foi ignorada pelo Sistema Econômico, sendo obtida pela soma da Demanda Exportada Ignorada (DEI) de cada material.

Figura 4 - Fluxos Componentes da Demanda Material Total (DMT) 2.3 Classificação dos materiais

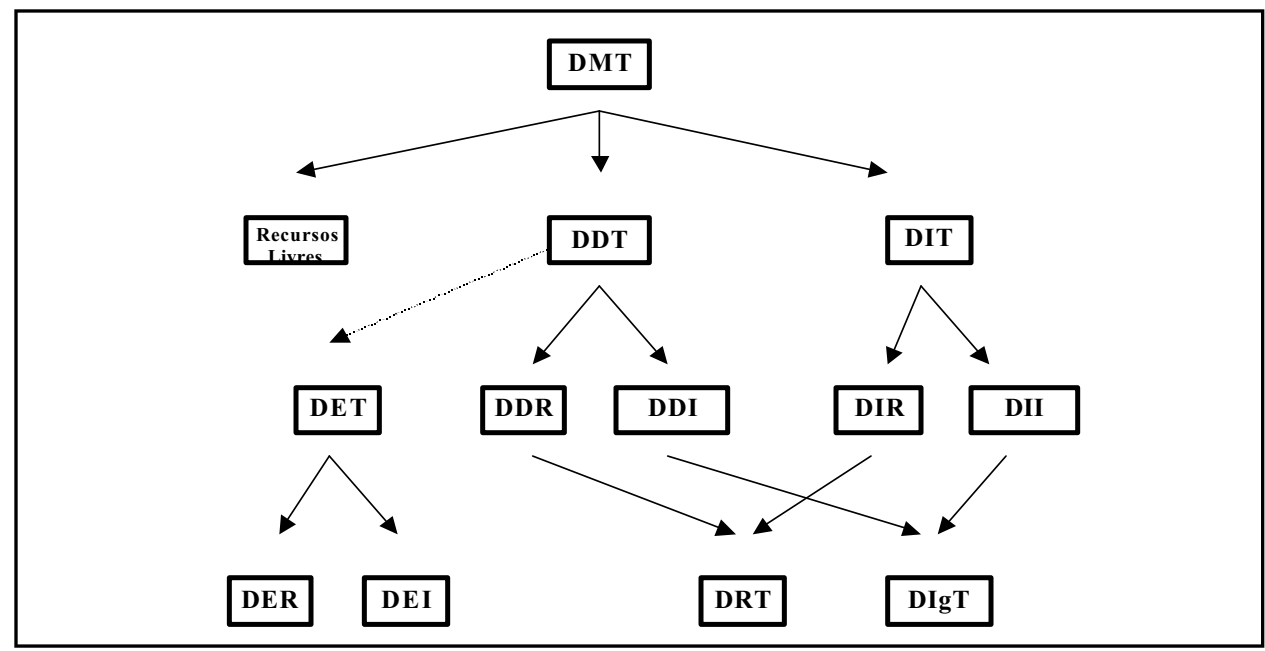

Fonte: Desenvolvimento do autor

${ }^{49}$ Esse fluxo, entretanto, não é considerado para a apuração da DMT, porque os materiais embutidos nessas exportações já tiveram sua contribuição contabilizada quando foram inicialmente apropriados pela economia. 
Os diferentes materiais componentes da DMT foram classificados em CLASSES, CATEGORIAS, GRUPOS e MATERIAIS. O código utilizado para identificá-los tem a seguinte estrutura:
$\mathrm{X}$
o primeiro dígito representa a CLASSE;
X.XX
os dois dígitos seguintes representam a CATEGORIA;
X.XX.XX
os próximos dois dígitos representam o GRUPO;
X.XX.XX.XX
os dois dígitos finais representam o MATERIAL em si.

Esse sistema permite classificar o conjunto dos materiais analisados da seguinte maneira:

Os materiais dos grupos Biomassa Vegetal (Agricultura Permanen-

\begin{tabular}{|c|c|c|c|}
\hline \multicolumn{2}{|c|}{ Materiais não-renováveis } & \multirow{2}{*}{\begin{tabular}{|l|}
$\mathbf{2 . 0 1 . 0 2}$ \\
2.01 .02 .01
\end{tabular}} & \multirow{2}{*}{$\begin{array}{l}\text { Biomassa animal } \\
\text { Criação animal - Abates } \\
\end{array}$} \\
\hline 1.01 & Minerais energéticos & & \\
\hline 1.01.01 & Combustíveis sólidos & 2.01.02.xx & xxxxxxxxxxxxxxxxxxxx \\
\hline 1.01 .01 .01 & Carvão & 2.01 .03 & $\begin{array}{l}\text { Semi-acab. - Biomassa } \\
\text { vegetal }\end{array}$ \\
\hline 1.01.01.xx & $\operatorname{xxxxxx}$ & 2.01 .03 .01 & Produtos diversos vegetais \\
\hline 1.01 .02 & Combustíveis líquidos & $2.01 .03 . \mathrm{xx}$ & xxxxxxxxxxxxxxxxxxx \\
\hline 1.01 .02 .01 & Petróleo & 2.01.04 & $\begin{array}{l}\text { Semi-acab. - Biomassa } \\
\text { animal }\end{array}$ \\
\hline 1.01.02.xx & $\operatorname{xxxxxxx}$ & 2.01 .04 .01 & Produtos diversos animais \\
\hline 1.01 .03 & Combustíveis gasosos & 2.01.04.xx & $\operatorname{xxxxxxxxxxxxxxxxxxxx}$ \\
\hline 1.01 .03 .01 & Gás natural & 2.01 .05 & $\begin{array}{l}\text { Semi-acab. - Biomassas } \\
\text { diversas }\end{array}$ \\
\hline $1.01 .03 . \mathrm{xx}$ & $\operatorname{xxxxxxxxx}$ & 2.01 .05 .01 & Gorduras e óleos \\
\hline 1.02 & Minerais metálicos & $2.01 .05 . \mathrm{xx}$ & xxxxxxxxxxxxxxx \\
\hline 1.02 .01 & Min. metálicos - Bens primários & \multicolumn{2}{|c|}{$3 \quad$ Erosão do solo } \\
\hline 1.02 .01 .01 & Alumínio & 3.01 & Erosão do solo \\
\hline $1.02 .01 . \mathrm{xx}$ & $\operatorname{xxxxxxxx}$ & 3.01 .01 & $\mathrm{Na}$ agricultura \\
\hline 1.02 .02 & Min. metál. - Bens concentrados & 3.01 .02 & Na silvicultura madeireira \\
\hline \multicolumn{2}{|c|}{1.02 .02 .01} & \multicolumn{2}{|c|}{3.01 .03} \\
\hline $1.02 .02 . x x$ & Xxxxxxxxxxxxxxxxxx & 3.01 .04 & Na criação animal \\
\hline 1.02 .03 & Min. metálicos - Bens em ligas & 3.01 .99 & $\begin{array}{l}\text { Na produção e biomassas } \\
\text { diversas }\end{array}$ \\
\hline 1.02 .03 .01 & Alumínio em ligas & \multicolumn{2}{|c|}{$\begin{array}{l}\text { Materiais industrializados sem } \\
\text { enquadramento }\end{array}$} \\
\hline 1.02.03.xx & $\operatorname{xxxxxxxxxxxxx}$ & 4.01 & Produtos semi-acabados \\
\hline 1.02 .04 & Min. metálicos - Em sucatas & 4.01.01 & Semi-acabados não-renováveis \\
\hline 1.02 .04 .01 & Sucatas de alumínio & 4.01 .01 .01 & Semi-acab. alumínio \\
\hline $1.02 .04 . \mathrm{xx}$ & xxxxxxxxxxxxxxxx & 4.01.01.xx & xxxxxxxxxxxxxxxxxxx \\
\hline 1.03 & Minerais industriais & 4.01.02 & Semi-acabados renováveis \\
\hline 1.03 .01 & Grupo único & 4.01 .02 .01 & xxxxxxxxxxxx \\
\hline 1.03 .01 .01 & Agua mineral & 4.01.02.xx & $\operatorname{xxxxxxxxxxxx}$ \\
\hline 1.03.01.xx & $\operatorname{xxxxxxxxxxx}$ & 4.01.03 & Outros semi-acabados \\
\hline 1.04 & Materiais de construção & 4.01 .03 .01 & $\operatorname{xxxxxxxxxxxx}$ \\
\hline 1.04 .01 & Grupo único & 4.01.03.xx & xxxxxxxxxxxx \\
\hline 1.04 .01 .01 & Areia e cascalho & 4.02 & Produtos manufaturados \\
\hline 1.04.01.xx & xxxxxxxxxxxxx & 4.02.01 & Manufaturados não-renováveis \\
\hline 1.05 & Material de escavação & 4.02 .01 .01 & Manufaturado Alumínio \\
\hline 1.05 .01 & Grupo único & 4.02.01.xx & 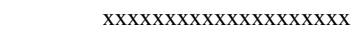 \\
\hline 1.05 .01 .01 & Construções mobiliárias & 4.02.02 & Manufaturados renováveis \\
\hline 1.05.01.xx & xxxxxxxxxxxxxxxxxxx & 4.02 .02 .01 & Prod. Ind. Alimentícios \\
\hline \multicolumn{2}{|c|}{$2 \quad$ Materiais renováveis } & 4.02.02.xx & xxxxxxxxxxxxxxxxxx \\
\hline 2.01 & Renováveis de biomassas & 4.02.03 & Outros manufaturados \\
\hline 2.01 .01 & Biomassa vegetal & 4.02 .03 .01 & $\operatorname{xxxxxxxxxxxxxxxxxx}$ \\
\hline 2.01.01.01 & Agricultura permanente & 4.02.03.xx & 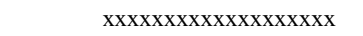 \\
\hline 2.01.01.xx & $\operatorname{xxxxxxxxxxxxxxxxx}$ & & \\
\hline
\end{tabular}


José Alberto da Costa Machado, Norbert Fenzl

te, Agricultura Temporária, Silvicultura Madeireira, etc.) e da Biomassa Animal (Criação Animal-Abates, Criação Animal-Produtos, Extrativismo da Pesca, etc) representam ainda grandes agregados, por isso, para efeito de coleta e cálculo, foram subdivididos em mais um nível, isto é, o dos produtos que os compõem. Os materiais específicos de cada classe poderão ser vistos, individualmente, nos relatórios contendo os resultados da pesquisa, em MACHADO (1999:Anexo-06). Para compatibilizar os resultados finais do trabalho com medições internacionais já divulgadas, eles foram apurados em nível de categoria, isto é, o segundo nível da estrutura utilizada para codificar os materiais.

Para a determinação da Demanda Doméstica Ignorada, os materiais são considerados apenas em dois dos seus diversos estados: o primeiro é o estado bruto em que o recurso se encontra na natureza; o segundo é o estado em que o recurso pode ser considerado um bem primário, portador de um valor monetário expressado em preço, independentemente da forma em que esteja. Já em relação à Demanda Importada ou Exportada Ignorada, há necessidade de se considerar o estado de transformação em que o material se encontra ao entrar ou sair na ou da economia nacional, pois, nesse caso, a mochila ecológica do material acresce-se das perdas ocorridas nos processos de transformação, já internos ao Sistema Econômico. Neste trabalho, para efetivar tais cálculos, foram considerados os seguintes estados de transformação: Recurso Natural Bruto - material in natura, tal como retirado da mina; Bem Primário - minério que já passou por processo de beneficiamento; Concentrado - bem primário submetido a processo de purificação (específico de minerais metálicos); Liga - Material fruto de junção de dois ou mais tipos de concentrados (específico de minerais metálicos); Sucata - material que retorna ao Sistema Econômico para reaproveitamento (específico de minerais metálicos); Semi-Acabado - material que sofreu transformação, mas ainda não assumiu forma definitiva para consumo ou uso final; Manufaturado - material que passou por todos os processos de transformação e que assumiu forma definitiva para consumo ou uso final.

\subsection{A classe Materiais Não-Renováveis}

Trata-se de materiais oriundos de reservatórios subterrâneos fósseis. São extraídos e absorvidos pelo Sistema Econômico, transformamse em utilidades e, ao final da vida útil, convertem-se em lixo com possibilidades limitadas para reciclagem. Esses materiais são chamados minério ou substância mineral e subdividem-se em ganga (fração não útil do minério) e mineral de minério, a fração útil do minério. O mineral 
é a substância natural ocorrente na crosta terrestre, representado por uma fórmula, e que é utilizado pelo Sistema Econômico para a produção das mercadorias.

Também são tidos como parte dessa classe, os materiais movimentados nas atividades de construção mobiliária, rodoviária e nas demais obras de infra-estrutura ${ }^{50}$. Esse material, chamado de Material de Escavação, tem sido considerado, por certos autores, demanda do Sistema Econômico. Neste trabalho, essa não é a posição adotada, pelas razões expostas a seguir.

O Metabolismo Econômico-Ambiental (MEA) é representado pelas ações e efeitos associados à manutenção e à expansão do Sistema Econômico, e a Colonização é representada pelas ações e efeitos associados à sua expansão. No primeiro caso, as ações visam apenas a sustentação do funcionamento corrente do sistema e, por isso, são contínuas no tempo e de ocorrência obrigatória, sem o que, o sistema morre; no segundo caso, as ações visam a dilatação das fronteiras estruturais do sistema e, por isso, podem ser descontínuas no tempo e ocorrer só quando existam condições favoráveis para tal. No primeiro caso, as demandas em relação ao Ambiente são feitas diretamente pelo Sistema Econômico; no segundo caso, elas são mediadas pelo Sistema Infra-Estrutura, conforme visto anteriormente. Assim, como o Material de Escavação é decorrente das obras de infra-estrutura, ele não pode ser considerado uma demanda diretamente relacionada ao Sistema Econômico, mas está relacionado ao Sistema Infra-Estrutura. Obviamente, o funcionamento deste é influenciado pelo funcionamento daquele, mas essa influência produz uma interferência de natureza diferente - a Colonização -, que só pode ser medida a partir da sua lógica própria e por meio de métricas consentâneas com a sua natureza e que não é objeto de estudo deste trabalho. Por essas razões, o Material de Escavação é um efeito a ser associado à Colonização ${ }^{51}$ e não ao $M E A$.

a) Cálculo dos fluxos domésticos

O fluxograma na Figura 5, construído a partir de DNPM (1998), ilustra o caminho seguido por esse tipo de material (Minerais Energéticos, Metálicos, Industriais e de Construção) desde o momento de sua

\footnotetext{
${ }^{50}$ Nessas atividades a superfície do solo é escavada e o material retirado vai servir como aterro em outras construções ou transforma-se em amontoados de entulhos passíveis de espalhamento sobre a superfície. Ambas as situações representam movimentação antrópica de matéria e produzem impactos sobre o Ambiente, conturbando a paisagem e expondo entulhos aos arrastamentos provocados pelas chuvas e ventos, com conseqüências similares às da erosão do solo nas atividades agrosilvipastoris.

${ }^{51}$ A métrica que tem sido associada à Colonização é o "espaço ambiental ocupado". Como o trabalho não está tratando especificamente dessa dinâmica, não haverá maiores considerações sobre a questão. Entretanto, com base nas razões que estão sendo apresentadas para o descarte da categoria Material de Escavação como integrante do MEA, fica claro que os materiais dessa categoria deveriam integrar qualquer sistema métrico construído para avaliar o comportamento do Sistema InfraEstrutura e sua dinâmica básica, a Colonização .
} 
extração até ser considerado um bem econômico primário.

A produção bruta ${ }^{52}$ de minério é representada pela soma do minério extraído da mina (A) com o minério bruto oriundo de outras minas (B). Essa produção bruta pode ser dividida em três partes que ganham destinos diferentes, a saber: a primeira (C) é a parcela encaminhada para tratamento, isto é, aos processos que visam a retirada da fração não útil, os quais vão dar origem à produção beneficiada, ou seja, o minério transformado em utilidade beneficiada a ser transferida para a industrialização (M) ou negociada em mercado com as indústrias independentes $(\mathrm{G})$ e com os consumidores finais (F); a segunda (D) é a parcela encaminhada para a transformação (industrialização) pelos mesmos titulares da lavra, isto é, trata-se do minério que será transformado diretamente em mercadoria e cujo processo de beneficiamento é integrado à industrialização; a terceira (E) é a parcela encaminhada para as vendas no mercado de utilidades brutas, isto é, é o minério bruto que vai ser vendido ou para ser tratado em outras minas $(\mathrm{H})$, ou para ser negociado diretamente com as indústrias (I), ou para ser tratado por beneficiadores independentes $(\mathrm{J})$ ou para ser consumido in natura (K). Os beneficiadores independentes, após os processos de tratamento, negociam esses materiais com as indústrias (L).

${ }^{52}$ Este e os demais termos sublinhados deste parágrafo representam variáveis utilizadas pelas estatísticas utilizadas como fonte. 
Figura 5 - Fluxo do Minério entre Ambiente e Sistema Econômico

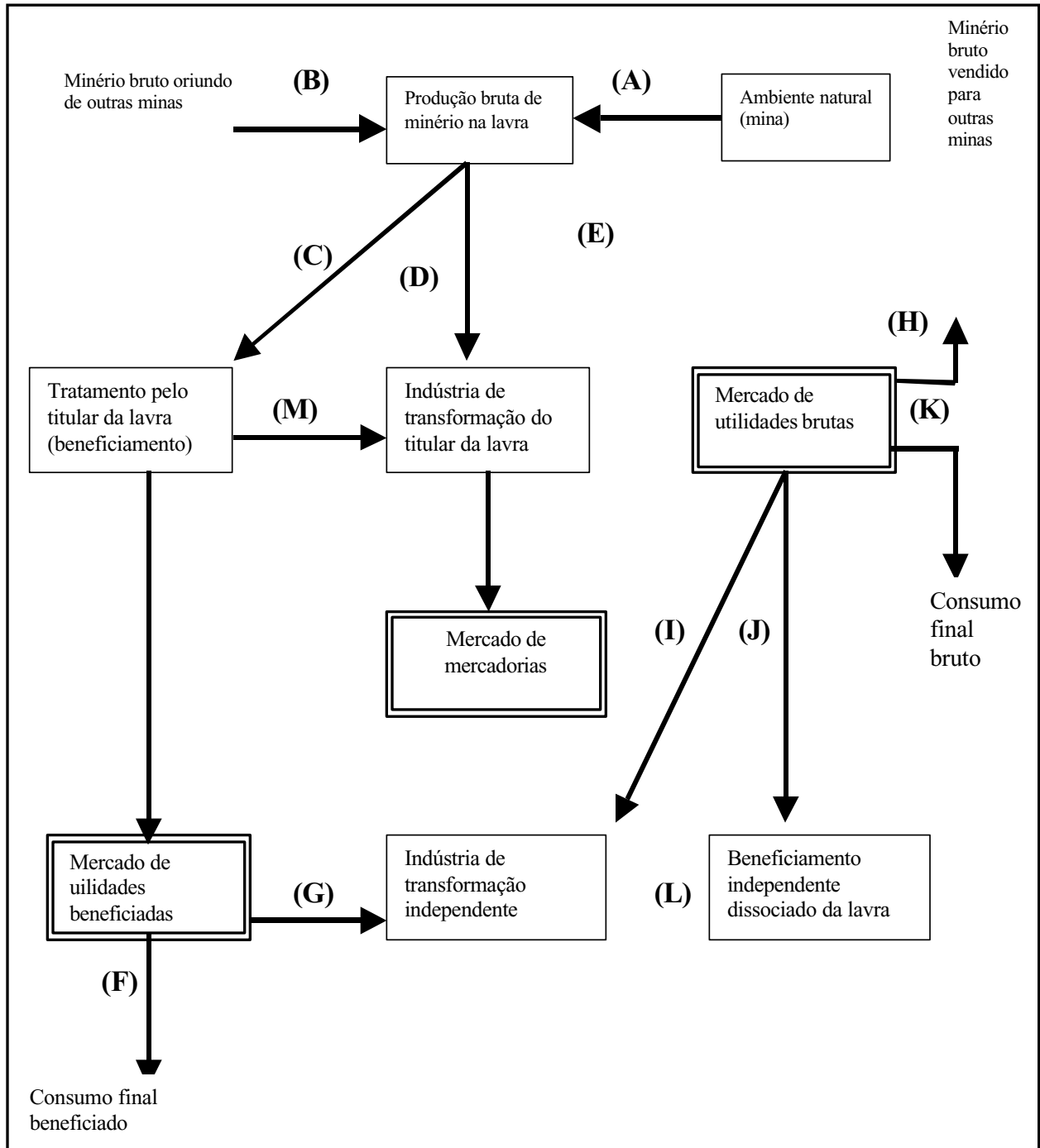

Fonte: Desenvolvimento do autor

Com base no fluxo descrito, considerou-se o total da produção beneficiada (o minério que recebeu tratamento e que é transferido para a industrialização (M) ou negociado com a indústria de transformação independente $(G)$ e consumidores finais $(F)$ ) como o quantitativo que melhor expressa a Demanda Doméstica Reconhecida (DDR) do Sistema Econômico, pelas seguintes razões: (i) a parte mais significativa do que é destinado ao mercado de utilidades brutas (E) acaba voltando $(\mathrm{H})$ a ser considerada produção bruta (B), portanto não se transforma em utilidade para o Sistema Econômico; (ii) o que é encaminhado bruto para a transformação (D) é inexpressivo, uma vez que qualquer tratamento 


\section{José Alberto da Costa Machado, Norbert Fenzl}

prévio $^{53}$ aplicável ao mineral antes de ser industrializado é considerado beneficiamento, por isso, contado como encaminhado para tratamento.

Assim, a produção beneficiada foi considerada a Demanda Doméstica Reconhecida (DDR) de cada material. A diferença entre produção bruta e produção beneficiada foi considerada a Demanda Doméstica Ignorada (DDI), ou seja, as perdas que ocorrem antes que os recursos extraídos se transformem em bens reconhecidos pelo Sistema Econômico.

Entretanto, existem diversos minérios que, a partir do mercado de utilidades brutas, são destinados, reconhecidamente, ao atendimento direto de demandas reais (K) do Sistema Econômico, não sendo re-encaminhados ao tratamento em outras unidades da indústria extrativa (H). Esse é o caso, sobretudo, de vários materiais de construção, como, por exemplo, o granito, a areia, o mármore, etc. Isso significa que essas vendas são parte da Demanda Doméstica Reconhecida (DDR) e, por essa razão, precisam ser consideradas como tais.

Assim, a apuração da DDR e DDI de cada componente da classe Não-Renováveis, obedeceu às seguintes regras ${ }^{54}$ :

Regra geral (aplicada como padrão e utilizada para a maioria dos materiais):

DDR $=$ Produção beneficiada

DDI $=$ Produção bruta - Produção beneficiada

Regra específica (para materiais demandados em forma bruta pelo Sistema Econômico):

DDI = Produção encaminhada para tratamento - Produção beneficiada

DDR $=$ Produção bruta - DDI

No uso da regra específica, está implícito que a produção bruta não encaminhada para o tratamento é absorvida, in natura, pelo Sistema Econômico. Por conseqüência, fica implícito também que as perdas de matéria (DDI) só ocorrem em relação ao que é encaminhado para tratamento 55 .

\footnotetext{
${ }^{53}$ A metodologia que embasa a produção das estatísticas utilizadas como fonte deste trabalho considera como encaminhado para tratamento todo minério que foi submetido a um dos seguintes processos: beneficiamento, realizado por fragmentação, pulverização, classificação, concentração, homogeneização, desaguamento e levigação; aglomeração, realizada por briquetagem, nodulação, sinterização e pelotização; beneficiamento, ainda que exija adição de outras substâncias, desde que não resulte em modificação essencial da identidade das substâncias minerais processadas (DNPM, 1998:4).

${ }^{54}$ Os termos das fórmulas são variáveis presentes nas estatísticas que serviram de fonte.

${ }^{55}$ A experiência deste trabalho revelou a possibilidade de se ter uma regra única. Esta não elimina todas as distorções, mas torna seus efeitos inexpressivos. Veja-se abaixo:

$\underline{\text { DDI-Registrada }}=$ Produção bruta encaminhada para tratamento - Produção beneficiada

Fator de Perda = (DDI-Registrada X 100) / Produção bruta encaminhada para tratamento

DDI-Inferida $=$ (Produção bruta encaminhada para transformação X Fator de perda) + (Produção bruta encaminhada para venda $\mathrm{X}$ Fator de perda)

$D D I=$ DDI-Registrada + DDI-Inferida.
} 
b) Cálculo dos fluxos de comércio exterior

Trata-se dos materiais que entram ou saem na ou da economia como importados ou exportados 56 . As informações básicas sobre essas importações e exportações são obtidas das estatísticas de comércio exterior referente a cada material, presentes em DNPM (1976-96). Para o cálculo da Demanda Ignorada, tanto importada quanto exportada, é necessário conhecer o estado de transformação em que o material se encontra e os coeficientes aplicáveis para determinar as perdas materiais já ocorridas até aquele estágio. Esses coeficientes estão associados à origem do material, uma vez que as perdas com ele serão dependentes da tecnologia utilizada em sua extração, das condições naturais de suas reservas, do grau de pureza em que ocorrem, etc. Por serem muitos os fatores condicionantes de um cálculo preciso e como o objetivo principal do trabalho é a obtenção de grandezas aproximadas, optou-se por determiná-los por meio das seguintes alternativas: (i) em relação à Demanda Importada Ignorada (DII), utilizou-se ou o parâmetro internacional (quando encontrado na literatura de referência), ou a média da DDI (quando esta era passível de cálculo consistente), ou ficou sem ser calculada; (ii) em relação à Demanda Exportada Ignorada (DEI), a base foi a própria Demanda Doméstica Ignorada (DDI) ${ }^{57}$.

\subsection{A classe Materiais Renováveis}

A classe Materiais Renováveis possui uma única categoria, os Renováveis de Biomassa, com a seguinte estruturação:

\section{2 - MATERIAIS RENOVÁVEIS}

2.01 - RENOVÁVEIS DE BIOMASSA

2.01.01 - Biomassa vegetal

2.01.01.01-Agricultura permanente

2.01.01.02-Agricultura temporária

2.01.01.03-Silvicultura-Madeiras

2.01.01.04-Silvicultura-Diversos

2.01.01.05-Extrativismo vegetal - Madeiras

\subsubsection{2 - Biomassa animal}

2.01.02.01-Criação animal - Abates

2.01.02.02-Criação animal - Produtos

2.01.02.03-Extrativismo animal - Pescados

2.01.03 - Semi-acabados de biomassa

vegetal

2.01.03.01- Produtos diversos do reino vegetal

2.01.03.02-Matéria-prima-Fabricação

papel

2.01.03.03-Matéria-prima para têxteis

\footnotetext{
${ }^{56}$ Ressalte-se que materiais importados e exportados não enquadráveis numa das categorias básicas utilizadas no trabalho são contados em uma categoria específica - Materiais Industrializados sem Enquadramento

${ }^{57}$ Essa opção só expressa um patamar mínimo de perdas materiais. É que, entre a entrada do material no Sistema Econômico (momento do cálculo da DDI) e a sua saída como produto exportado, há, certamente, perdas materiais decorrentes do processo de transformação pelo qual passa para poder ser exportado. Não havendo métodos seguros para determinar essas perdas, optou-se por usar como base a Demanda Doméstica Ignorada (DDI) associada ao material, uma vez que, com certeza, pelo menos essas perdas estão associadas aos produtos exportados.
} 
José Alberto da Costa Machado, Norbert Fenzl

\begin{tabular}{|c|c|}
\hline 2.01.01.06-Extrativismo vegetal - Borrachas & $\begin{array}{l}\text { 2.01.04 - Semi-acabados de biomassa } \\
\text { Animal }\end{array}$ \\
\hline $\begin{array}{l}\text { 2.01.01.07-Extrat. vegetal - Gomas } \\
\text { não-elásticas }\end{array}$ & $\begin{array}{l}\text { 2.01.04.01-Produtos diversos do reino } \\
\text { Animal }\end{array}$ \\
\hline 2.01.01.08-Extrativismo vegetal - Ceras & 2.01.04.02-Carnes e Conexos \\
\hline 2.01.01.09-Extrativismo vegetal - Fibras & 2.01.04.03-Peles e Couros \\
\hline $\begin{array}{l}\text { 2.01.01.10- Extrativismo vegetal - } \\
\text { Oleaginosas }\end{array}$ & $\begin{array}{l}\text { 2.01.05 - Semi-acabados de } \\
\text { Biomassas diversas }\end{array}$ \\
\hline $\begin{array}{l}\text { 2.01.01.11-Extrativismo vegetal-Tanantes } \\
\text { 2.01.01.12-Extrativismo vegetal-Alimentícios } \\
\text { 2.01.01.13-Extrat. vegetal - Aromáticos }\end{array}$ & 2.01.05.01- Gorduras e Óleos \\
\hline ledicinais & \\
\hline
\end{tabular}

Na estruturação acima, o nível mais analítico representa ainda agregações de outros componentes. Por exemplo: Agricultura Permanente é o agregado de todos os produtos agrícolas originados de cultura permanente, tais como o abacate, a laranja, a maçã, a banana, etc; Silvicultura - Madeira é o agregado de todos os produtos madeireiros oriundos de florestas cultivadas, tais como madeira para carvão, para lenha, para papel e celulose, etc; Extrativismo Vegetal - Alimentícios é o agregado de todos os produtos alimentícios oriundos do extrativismo, tais como açaí, castanha-do-Pará, erva-mate, etc; Semi-Acabados (Vegetal, Animal e Outros) são agregados de todos os produtos de biomassa que foram importados ou exportados e foram obtidos, já agregados, das estatísticas do comércio exterior presentes em IBGE (1976-96). A apuração das demandas dos materiais da classe foi feita com base nos componentes desses agregados e está demonstrada em MACHADO (1999:Anexo 07).

\section{a) Cálculo dos fluxos domésticos 58}

O grupo Biomassa Vegetal é composto pela produção doméstica oriunda da agricultura, da silvicultura e do extrativismo vegetal. O fluxo reconhecido desses materiais é formado pela somatória dos pesos líquidos dos principais produtos que compõem essa produção. Por peso líquido, considera-se a biomassa vegetal transformada em utilidade. Já a parte dessa produção que não se transforma em utilidade é contada como fluxo ignorado. Por exemplo, a madeira que entra na serraria é considerada fluxo reconhecido e as folhas, galhos e árvores destruídos durante a extração são contados como fluxos ignorados. A fonte de dados foi o Anuário Estatístico do Brasil na seção referente às Atividades

${ }^{58}$ Para a classe Materiais Renováveis, esses fluxos só ocorrem para os grupos Biomassa Vegetal e Biomassa Animal.

106 
Agropecuária e Extração Vegetal. Para o processo de coleta foram tomados como referência os padrões descritos a seguir.

i) Na Agricultura Permanente e Temporária, alguns produtos que aparecem, na fonte de coleta, expressados em unidades diferentes do peso, foram transformados, para essa métrica, por fatores específico a cada produto, determinados, especialmente, para o trabalho.

ii) Para a Silvicultura-Madeira e Extrativismo Vegetal-Madeira, são válidos os seguintes padrões: (1) o metro cúbico foi transformado para tonelada com base na taxa média de 0,803, obtida de relatório de pesquisa recentemente publicado pelo Instituto Nacional de Pesquisas da Amazônia em conjunto com o Department for International Development da Inglaterra (HIGUCHI et al., 1997a:53); (2) a taxa de perda, isto é, a biomassa perdida no processo de extração, foi calculada à taxa média de 1,9, obtida de pesquisa recente sobre danos da extração madeireira (UHL, 1996:2759). Essa taxa indica que, para cada metro cúbico de madeira que entra na serraria, quase dois metros cúbicos são desperdiçados pelo processo.

O grupo Biomassa Animal é composto pela produção interna oriunda da criação e do extrativismo animal. Os animais domésticos, peixes e outras fontes de biomassa animal só são contados quando alimentados com produtos não-agrícolas. Os animais criados com base em rações ou em produtos adquiridos em mercado e os peixes criados por aqüicultura não são considerados, porque os produtos utilizados para alimentálos já foram contabilizados quando seus componentes foram extraídos do Ambiente. A fonte de dados foi o Anuário Estatístico do Brasil na seção referente às Atividades Agropecuária e Extração Vegetal. Para o processo de coleta foram tomados como referência os padrões abaixo descritos.

iii)Para Criação Animal-Abates, são válidas as seguintes considerações: (1) Os abates de bovinos, eqüídeos, ovinos e caprinos, por terem sido considerados como criados em pastagens, foram contabilizados na totalidade 60 . Já o abate dos demais (suínos, coelhos, aves, etc), porque criados com base em ração, não foram contabilizados. Essa ração já foi contabilizada quan-

\footnotetext{
${ }^{59}$ HIGUCHI et al. (1997b:126) apresentam uma taxa de 0,7. Entretanto, a pesquisa que embasa esse resultado foi feita para exploração planejada, o que não é o caso da maioria da exploração extrativa de madeira. Já o resultado de 1,9, usado como padrão para este trabalho, foi obtido de pesquisa que incluiu extração de baixo e alto impacto e também planejada.

${ }^{60}$ Existem, certamente, criações desses animais em regime de confinamento, isto é, baseado totalmente em ração. Entretanto, segundo pesquisadores da EMBRAPA, o percentual do rebanho criado nessas condições é mínimo e não chega a 5\% (TEIXEIRA, 1998).
} 
José Alberto da Costa Machado, Norbert Fenzl

do seus componentes foram extraídos do Ambiente. (2) Para o cálculo dos fluxos referentes aos bovinos, os quais representam a quase totalidade dos abates animais, foi tomada por base a seguinte composição média de uma rês com peso vivo médio de $370 \mathrm{~kg}$, conforme CARNEIRO (1981): carcaça 197,0kg, 53,2\%; estrume 48,0 kg, 13,0\%; víscera 46,0 kg, 12,5\%; couro 30,0 kg, 8,1\%; sangue 19,0 kg, 5,1\%; sebo 17,0 kg, 4,6\%; água 9,8 kg, 2,6\%; cascos e chifres 3,0 kg, 0,8\%; crina 0,2 kg, 0,1\%. (3) Da composição acima, considerou-se fluxo reconhecido a carcaça, as vísceras, o couro, o sebo, os cascos e chifres e a crina, porque são esses os produtos comercializáveis. Como fluxo ignorado foi considerado o estrume, o sangue e a água, porque são esses os componentes da rês que se perdem no processo de abate. (4) Os quantitativos referentes aos bovinos foram calculados tomando-se por base o peso total das carcaças abatidas, que são publicadas na fonte dos dados. Com base no peso das carcaças e no conteúdo da composição acima, foram calculados os demais componentes que compõem os fluxos oriundos de bovinos. (5) Os quantitativos referentes aos eqüídeos, ovinos e caprinos foram calculados com base na quantidade de cabeças abatidas e tendo por base os seguintes pesos médios: eqüídeos $180 \mathrm{~kg}$, ovinos $30 \mathrm{~kg}$ e caprinos $25 \mathrm{~kg}$. Por serem inexpressivos, os fluxos ignorados não foram calculados para esses animais.

iv) Para Criação Animal-Produtos são válidas as seguintes considerações: (1) os produtos considerados foram somente aqueles oriundos de animais que são sustentados diretamente pelo Ambiente, por isso, ovos de galinha e de codorna não foram considerados; (2) o leite foi contabilizado em litros e transformado para peso na taxa de 1 litro $=1 \mathrm{~kg}$.

v) Para Extrativismo Animal são válidas as seguintes considerações: (1) não há registro de caça; (2) a fonte básica da coleta de dados não publicou os dados referentes à pesca para os anos de $1990 \mathrm{a}$ 1995, eles foram obtidos de relatório interno do Instituto Brasileiro de Recursos Naturais e Meio Ambiente (IBAMA, 1995).

b) Cálculo dos fluxos do comércio exterior ${ }^{61}$

Para a apuração dos fluxos ignorados associados às importações de materiais renováveis, foi utilizado o mesmo fator do Japão. Esse fa-

${ }^{61}$ Esses fluxos, na classe Materiais Renováveis, só ocorrem para os grupos Semi-Acabados de Biomassa Vegetal, Semi-Acabados de Biomassa Animal e Semi-Acabados de Biomassas Diversas. 
tor, similar para todos os anos da série, foi de 5,5 tons por cada tonelada importada de biomassa, tanto vegetal quanto animal. Assim, essa mesma taxa foi aplicada ao total dos grupos Semi-Acabados de Biomassa Vegetal, Semi-Acabados de Biomassa Animal e Semi-Acabados de Biomassas Diversas, em todos os anos da série. Já para a apuração da Demanda Exportada Ignorada de cada ano, a base foi a própria Demanda Doméstica Ignorada do ano considerado ${ }^{62}$.

\subsection{A classe Erosão de Solo}

O solo erodido63 pelas atividades agrícolas representa o material movimentado para a obtenção dos materiais renováveis utilizados pelo homem. Ele representa uma espécie de Demanda Ignorada dessas atividades, mas, em razão da sua natureza e dimensão, está sendo considerado uma classe à parte. Existe uma fórmula universal para o calculo da perda de solo64 , entretanto essa fórmula só é aplicável em condições específicas e localizadas, por isso ela não pode ser usada quando se intenta calcular essas perdas para toda a economia de um país, como é o caso deste trabalho. Assim, procurou-se fazer esse cálculo tomando por base as taxas de perdas de solo no cultivo dos principais produtos presentes nas fontes de dados, assumindo-se que elas são similares para toda a produção daquele produto independente da origem geográfica da produção ${ }^{65}$. Também, quando não foi possível encontrar na literatura taxas específicas para todos os produtos presentes na fonte de dados, utilizaram-se taxas gerais: 25 ton/ha para agricultura temporária e 0,9 para agricultura permanente. Essas taxas gerais, apesar de legitimadas pelo uso constante na literatura (MUSEU EMÍLIO GOELDI, 1999:28), não tive-

\footnotetext{
${ }^{62}$ Essa opção só expressa um patamar mínimo de perdas materiais. É que, entre a entrada do material no Sistema Econômico (momento do cálculo da DDI) e a sua saída como produto exportado, há, certamente, perdas materiais decorrentes do processo de transformação pelo qual passa para poder ser exportado. Não havendo métodos seguros para a determinar essas perdas, optou-se por usar como base a Demanda Doméstica Ignorada (DDI) associada ao material, uma vez que, com certeza, pelo menos essas perdas estão associadas aos produtos exportados.

${ }^{63}$ Na descrição de VIEIRA (1996:193), a erosão é o processo de desagregação, decomposição de solos e rochas. No sentido geológico amplo, é um processo natural, continuamente atuante e o principal agente do desgaste das partes mais altas da paisagem para a constituição das planícies onde são encontrados solos geralmente de alta fertilidade natural. Entretanto, as atividades humanas sobre a paisagem também provocam o desgaste do solo pela retirada da sua capa protetora, o que possibilita uma intensa ação da água da chuva e do vento, dando origem a uma erosão socialmente produzida (EMBRAPASNLCS, 1980).

${ }^{64}$ A equação universal para o cálculo da perda de solo devido à erosão provocada por cultivos agrícolas tem a seguinte fórmula: A = R.K.SL.P.C, onde A é a perda de solo calculada por unidade de área; R é um índice numérico que representa a capacidade da chuva de causar erosão em uma área desprotegida, em determinado local; K é a erodibilidade local do solo; LS é o cumprimento e o grau do declive do local; C é a relação entre perdas de solo de um terreno cultivado e as perdas de um terreno correspondente mantido continuamente descoberto; P é a relação entre perdas de solo de um terreno cultivado com determinadas práticas e as perdas quando é feito o plantio morro abaixo (VIEIRA, 1996:233).

${ }^{65}$ Apesar dessa generalização, os totais resultantes dos cálculos feitos para este trabalho, em relação à erosão de solo no cultivo agrícola, estão próximos daqueles publicados na literatura específica. Há estimativas (MUSEU EMÍLIO GOELDI, 1999:28) de que se perde, anualmente, em torno de 1 bilhão de toneladas devido às atividades agrícolas, e este trabalho encontrou um perda média, nos últimos oito anos do período de referência, em torno de 950 milhões.
} 


\section{José Alberto da Costa Machado, Norbert Fenzl}

ram grande influência nos resultados finais deste trabalho, pois que o percentual dessa erosão calculado com base em taxas gerais representou apenas em torno de $12 \%$ do total geral da erosão de solo.

Essa classe possui uma única categoria titulada também de Erosão do Solo, a qual foi dividida em dois grupos: Agricultura e Criação Animal ${ }^{66}$. Os materiais que compõem esses grupos são os mesmos que integram os grupos de mesmo nome na classe Renováveis. Como esse material não se incorpora fisicamente às utilidades movimentadas pelo Sistema Econômico, ele só existe como Demanda Ignorada, tanto Doméstica como Importada.

\section{a) Cálculo dos fluxos domésticos}

i) $\mathrm{Na}$ Agricultura o cálculo da perda de solo foi feito com base em duas variáveis: área destinada à colheita e taxa de perda de solo nas culturas dos principais produtos agrícolas. As taxas seguem adiante com o nome do produto, as toneladas anuais por hectare e a fonte de onde foi retirada a taxa: culturas temporárias - algodão herbáceo, 24,8, BERTOLONI e LOMBARDI NETO (1990:59-61); arroz, 25,1, idem; amendoim, 26,7, idem; batata-doce, 6,6, idem; batata-inglesa, 18,4, idem; cana-deaçúcar, 12,4, idem; feijão, 38,1, idem; mamona, 41,5, idem; mandioca, 33,9, idem; milho, 12,0, idem; soja, 20,1, idem; trigo, 10,0, IAC (1989); fator geral para culturas temporárias (anuais), 25,0, IAC (1989) e MUSEU EMÍLIO GOELDI (1999:28); culturas permanentes: algodão arbóreo, 26,6, VIEIRA et al. (1996:283); banana, 0,9, IAC (1989); café, 1,4, NEVES (1980:26); laranja, 0,9, IAC (1989); fator geral para culturas permanentes, 0,9, idem.

ii) Na Criação Animal o cálculo da perda de solo foi feito com base em três variáveis: o rebanho, a taxa de lotação das pastagens e a taxa de perda de solo nas pastagens. Sabendo-se o total do rebanho e a taxa de lotação, pode-se deduzir a área ocupada

\footnotetext{
${ }^{66} \mathrm{Na}$ Silvicultura - Madeira e no Extrativismo Vegetal - Madeira, também ocorre perda de solo. Para a realização dessas atividades, há necessidade de preparação de estradas e de pátios de armazenagem que deixam grandes aberturas tanto na superfície da terra quanto no dossel da floresta, expondo o solo ao impacto direto da chuva e, portanto, da lixiviação. UHL (1996:27), com base em experimentos, estima que são abertos, entre pátios e estradas, $218 \mathrm{~m} 2$ na superfície e $662 \mathrm{~m} 2$ no dossel, para cada árvore extraída. Considerando-se que são extraídas, em média, 6,4 árvores por hectare, pode-se concluir que são abertos 1.395, $2 \mathrm{~m} 2$ de estradas e 4.236,8 m2 de dossel por hectare explorado. Tendo em vista, com base na mesma fonte, que são extraídos $38 \mathrm{~m} 3$ por hectare explorado, pode-se deduzir que há abertura de $36,71 \mathrm{~m} 2$ por cada metro cúbico extraído de madeira. Entretanto, como não há informações confiáveis sobre taxas de perda de solo em áreas de extrativismo e silvicultura madeireira, fica difícil fazer estimativas seguras a respeito, por isso essas perdas não foram consideradas neste trabalho. É necessário, na continuidade das pesquisas deste tema, definir bases sólidas para fazer essas estimativas, uma vez que a perda de solo nessas atividades parece possuir grande expressão.
} 
com pastagens para a manutenção anual do rebanho. Com essa área e a perda de solo por hectare de pastagens, pode-se calcular a erosão total decorrente da Criação Animal. Os dados sobre o rebanho foram coletados da fonte de dados, a taxa de lotação utilizada foi de 0,6 rês/ha (MARTIN, 1993:15) e a taxa de perda de solo em pastagem foi de 0,4 ton/ha67 (VIEIRA et al., 1996:223).

\section{b) Cálculo dos fluxos do comércio exterior}

Com a importação de biomassas, importa-se também erosão de solo. Esta, para ser calculada, requer cálculo complexo, conforme pode ser constatado em relação aos cálculos feitos para a apuração da erosão de solo doméstica. Assim, tomaram-se por referência os dados do Japão e calculou-se, ano a ano, a relação existente entre a perda de solo importada e a quantidade de biomassa importada ${ }^{68}$. Para a apuração da perda de solo exportada, tomou-se como base, ano a ano, a perda de solo doméstica na produção de biomassa e as exportações dessa biomassa.

\subsection{A classe Materiais Industrializados sem Enquadramento 69}

De maneira geral, a maioria dos produtos negociados com o exterior pode ser classificada, dentro do fluxo Demanda Importada ou Demanda Exportada, diretamente em uma classe específica. Mas, entre esses produtos, existem aqueles que já sofreram algum processo de transformação e que, em razão disso, necessitam de critérios adicionais para serem contabilizados. Esses critérios são oriundos de duas situações distintas que os caracterizam: a primeira relaciona-se com aqueles materiais que, apesar das transformações, não se distanciaram da natureza original da classe que os caracteriza e, por isso mesmo, continuam enquadrados nessa classe (ex: Ligas Metálicas e Concentrados da classe Não-Renováveis); a segunda relaciona-se com aqueles materiais que, após sofrerem as transformações, distanciaram-se da natureza original da classe que os caracterizava e, por essa razão, não são mais

\footnotetext{
${ }^{67}$ NEVES (1980:26) estima que a erosão de solo em pastagens é de 1 ton/ha. No trabalho foi usada a taxa menor para manter os cálculos dentro do espírito mais conservador possível.

${ }^{68}$ O Japão foi tomado como base porque somente seus dados apresentaram desagregação em detalhes suficientes para calcular a relação acima

${ }^{69}$ Essa classe é tratada na literatura como Material Importado. Mas essa designação expressa a origem do material e não sua natureza, o que produz confusão metodológica porque confunde duas categorias conceituais distintas: a classe - utilizada para agregar materiais de natureza similar - e ofluxo-utilizado para agregar os materiais em função da origem e destino. Ademais, isso ofusca o fato de que existem importados nas outras classes e impede de associarmos a ela as exportações. Por isso, neste trabalho, essa classe assume uma natureza distinta daquela que lhe é associada na literatura.
} 


\section{José Alberto da Costa Machado, Norbert Fenzl}

passíveis de enquadramento em qualquer das demais classes. Essa segunda situação é bem típica dos produtos manufaturados, que são uma composição de materiais de classes distintas e também de alguns SemiAcabados de Não-Renováveis e Renováveis. Assim, a classe descrita nesta seção, destina-se a aglutinar o material importado ou exportado pela economia, que, pela sua natureza, não foi passível de enquadramento em uma das demais classes.

\section{a) Cálculo dos fluxos da classe}

A classe em discussão não possui fluxo de origem doméstica porque ela só envolve material oriundo do exterior ou destinado ao exterior. Os dados dos fluxos reconhecidos foram retirados do capítulo sobre comércio exterior do Anuário Estatístico do Brasil. Valem para esta classe as seguintes observações: (i) a categoria Manufaturados teve sua contabilização apenas pelas tonelagens diretas de seus materiais componentes, sem considerar os fluxos ignorados - isso ocorre pela ausência de alternativas capazes de calcular esses fluxos dando conta da diversidade de componentes que faz parte da composição de qualquer produto manufaturado; (ii) os fluxos ignorados da categoria Semi-Acabados foram contabilizados tomando-se por base a taxa utilizada pelo Japão de 4 tons por tonelada importada ou exportada; (iii) os dados de importação e exportação utilizados no trabalho, como todos os demais, foram coletados em nível de cada produto componente das classes. Ocorre que, quando as totalizações desses dados (Demanda Reconhecida Importada e Demanda Reconhecida Exportada) foram comparadas aos totais gerais relacionados com o comércio exterior, registraram-se diferenças. Assim, para contabilizar essas diferenças, foram criados dois grupos de "Outros": um na categoria Semi-Acabados e outro na categoria Manufaturados.

\subsection{Informações complementares sobre a obtenção dos dados}

Os dados de PIB (Produto Interno Bruto) dos países foram compostos a preços constantes, base 1985 e na unidade Dólar-PPP70 . (i) Para os EUA, a composição foi feita com base nas seguintes fontes: (i.1) até 1992 o PIB foi obtido de NBER (1996), multiplicando-se a coluna de PIB Real Per Capita (R GDP/capita in constant \$ (Chain Index) (1985 IP)) pela população obtida de US-BC (1998); (i.2) o PIB dos anos de 1993 e

\footnotetext{
${ }^{70}$ Dólar-PPP (purchasing-power parity) representa uma espécie de dólar internacional. A conversão de valores em uma determinada moeda para essa unidade leva em conta a quantidade de unidades monetárias dessa moeda que é necessária para comprar os mesmos bens que US\$1 pode comprar nos EUA. Uma completa descrição sobre essa métrica encontra-se em UN (1992). Há uma tabela de conversão para qualquer moeda, ano base 1985, publicada em UN (1994).
} 
1994 foi obtido pelo incremento anual de 2,6\%, que foi a taxa média de crescimento anual para o período, conforme WRI (1996:167). (ii) Para a Alemanha, a composição foi feita a partir da conversão dos dados publicados em ADRIAANSE et al. (1997:38), a qual se baseou no seguinte: (ii.1) como esses dados foram publicados em marco alemão, já a preço constante de 1985, a conversão deles para dólar-PPP teria que ser feita com base no poder de compra, em dólar, que o marco tinha em 1985; (ii.2) com base em UN (1994, Summary of 1985 Results. Table B), encontrou-se a taxa de 2,478 - isso significa que, tomando-se por referência o ano de 1985, eram necessários 2,478 marcos para comprar o mesmo que US\$1 podia comprar, nos EUA; (ii.3) aplicando essa taxa aos dados publicados na fonte anteriormente citada, obtém-se o PIB da Alemanha, atualizado a preços de 1985 e convertido à unidade padrão dólar-PPP (Purchasing-power parity). (iii) Para o Japão, a composição foi feita, como para a Alemanha, também a partir da conversão dos dados publicados em ADRIAANSE et al. (1997:38), a qual se baseou no seguinte: (iii.1) como esses dados foram publicados em iene, já a preço constante de 1985, a conversão deles para dólar-PPP teria que ser feita com base no poder de compra, em dólar, que o iene tinha em 1985; (iii.2) com base em UN (1994, Summary of 1985 Results. Table B), encontrou-se a taxa de 221,9 - isso significa que, tomando-se por referência o ano de 1985, eram necessários 221,9 ienes para comprar o mesmo que US\$1 podia comprar, nos EUA; (iii.3) aplicando essa taxa aos dados publicados na fonte anteriormente citada, obtém-se o PIB do Japão, atualizado a preços de 1985 e convertido à unidade padrão dólar-PPP (Purchasing-power parity). (iv) Para a Holanda, similarmente como para os EUA, a composição foi feita da seguinte maneira: (iv.1) até 1992 o PIB foi obtido de NBER (1996), multiplicando-se a coluna de PIB Real Per Capita (R GDP/capita in constant \$ (Chain Index) (1985 IP)) pela população obtida de US-BC (1998); (iv.2) para os anos de 1993 e 1994, o PIB foi obtido pelo incremento anual de 2,8\%, que foi a taxa média de crescimento anual para o período, conforme WRI (1996:166). (v) Para o Brasil, também como para os EUA, a composição foi feita com base nas seguintes fontes: (v.1) até 1992 o PIB foi obtido de NBER (1996), multiplicando-se a coluna de PIB Real Per Capita (R GDP/capita in constant \$ (Chain Index) (1985 IP)) pela população obtida de US-BC (1998); (v.2) para os anos de 1993 e 1994, o PIB foi obtido pelo incremento anual de 2,2\%, que foi a taxa média de crescimento anual para o período, conforme WRI (1996:167).

Em relação aos dados utilizados na pesquisa, algumas informações adicionais ainda precisam ser feitas. (vi) Como o objetivo é obter uma primeira aproximação em relação à magnitude da Demanda Mate- 
José Alberto da Costa Machado, Norbert Fenzl

ria Total (DMT) da economia brasileira, a preocupação maior foi com os materiais que possuem maior relevância para a economia, assim entendidos aqueles que, de alguma forma, tiveram registros com quantidades acima de quinhentas toneladas anuais nas estatísticas adotadas como fontes. (vii) A escala temporal de referência (1975-94) foi definida considerando-se há quanto tempo a discussão sobre desenvolvimento sustentável tem estado na agenda da sociedade, a fim de se avaliar os efeitos que essas discussões têm sobre a intensidade material das economias. Considerou-se, também, que é somente para esse período que existem estimativas internacionais para comparação. Estas, entretanto, somente chegam até 1994, mas as estimativas deste trabalho avançam até 1995 porque, para o caso do Brasil, desejava-se saber o efeito da estabilização econômica, que ocorreu a partir de 1994. (viii) Os números considerados como fluxos anuais expressam a quantidade de milhares de toneladas, de cada material, que saiu do Ambiente (biosfera e base abiótica de recursos) e foi apropriado pelo Metabolismo Econômico-Ambiental; (ix) Os dados sobre a população dos cinco paises tratados no trabalho foram retirados de US-BC (1998, Table 001. Total Midyear Population).

Ao longo desta descrição metodológica, diversas fontes foram citadas como suporte para a composição dos dados. Entretanto, as fontes principais que serviram de base para a coleta, referentes ao Brasil, foram:

\begin{tabular}{|c|c|}
\hline NÃO-RENOVAVEIS & DNPM (1976-96) \\
\hline Minerais energéticos & DNPM (1976-96) \\
\hline Minerais metálicos, industriais e de construções & não apresentados nesta versão do trabalho \\
\hline Material de escavação & IBGE (1976-96/Seção Atividades) \\
\hline RENOVÁVEIS & idemecuária e Extração Vegetal? \\
\hline Biomassa vegetal (cultivo agrícola) & Idem \\
\hline Biomassa vegetal (extrativismo) & idem até 1989; IBAMA (1995) \\
\hline Biomassa animal (criação animal) & descritos na seção 2.6 \\
\hline Biomassa animal (pesca) & DNPM (1976-96) e IBGE (1976-96/Seção \\
\hline EROSÃO DE SOLO & Comércio Exterior) \\
\hline ENTERIAIS INDUSTRIALIZADOS SEM
\end{tabular}

114 


\subsection{Sobre os dados dos EUA, Alemanha, Japão e Holanda}

Os dados referentes aos Estados Unidos, Alemanha, Japão e Holanda foram obtidos de publicação internacional, de 1997, titulada de Resource Flows: The Material Basis of Industrial Economies (ADRIAANSE et al., 1997). Embora obedeçam à mesma matriz metodológica, esses dados apresentaram algumas dificuldades, a saber: a) cada país publicou seus dados em relatório com estruturação própria, com distintos graus de detalhamento, com distintas formas de classificar e nominar os materiais considerados e com diferentes quantidades de itens; b) os dados referentes à exportação não foram incluídos nos relatórios básicos, exceto para a Holanda; c) o nível de apuração dos fluxos componente da DMT seguiu diversos critérios, especialmente com referência aos importados - alguns países apresentaram esses fluxos em nível de alguns materiais, outros somente em nível de grupos e outros ainda somente em nível de categoria; d) totalizações parciais foram feitas sem indicação clara das parcelas às quais se referem, assim como valores foram apresentados sem indicação do que está sendo totalizado (caso da Holanda, ADRIAANSE et al., 1997:53); e) alguns totais apresentam-se claramente com erros, como por exemplo: (i) caso do Japão (ADRIAANSE et al., 1997:46): o total dos fluxos ocultos das commodities importadas não confere com a soma das parcelas que a compõem; (ii) caso da Holanda (ADRIAANSE et al., 1997:54): o total geral (TMR) não confere com as parcelas que deveriam integrá-lo, tanto quanto esse mesmo total geral não confere com o total apresentado no sumário (ADRIAANSE et al., 1997:25); (iii) caso da Holanda (ADRIAANSE et al., 1997:53): o fluxo indireto de renováveis importados parece incluir tanto o direto renovável quanto o indireto renovável importado; f) os dados analíticos dos Estados Unidos deixam dúvidas quanto à consistência, porque eles se repetem, com uma mesma grandeza, por diversos anos consecutivos - com uma economia dinâmica e gigantesca, fica difícil aceitar que muitos dos seus dados não tenham sofrido alterações em longos períodos; g) outra questão duvidosa sobre os dados dos EUA é a magnitude da Demanda Doméstica Ignorada (DEI) do Carvão Mineral - esse material, exclusivamente por si, representa quase 50\% da Demanda Material Total (DMT) do país, essa relação parece exagerada e, pela grandeza, pode estar destorcendo, seriamente, os resultados obtidos para os EUA; $h$ ) os dados de 1994 da Holanda não foram incluídos para muitos itens, por essa razão foram estimados; i) as demandas ignoradas da Alemanha foram publicadas não por categoria, mas como total na classe de Não-Renováveis, sob o título de "Non-saleable production". Para dis- 
José Alberto da Costa Machado, Norbert Fenzl

tribuí-las por categoria, utilizou-se a proporção incidente no ano de 1991, a qual foi retirada do sumário (ADRIAANSE et al., 1997:25). Os percentuais utilizados foram 92\% para Minerais Energéticos, 1,4\% para Minerais Industriais e 6,6\% para Minerais de Construção.

Há dois aspectos relevantes em relação aos dados desses países. (j) A categoria Material de Escavação foi desconsiderada no processo de conversão, pelos motivos já descritos na seção que tratou dessa categoria. Essa é uma razão pela qual a Demanda Material Total publicada na fonte de coleta difere da considerada neste trabalho. $k$ ) No relatório desses países, a classe 4 aparece com o título de Materiais Importados; nos relatórios do Brasil, ela tem título de Materiais Industrializados sem Enquadramento. Essa é uma mudança não apenas de título, mas também de conceito, com implicações também na forma de contabilizar os dados da classe, como pode ser constatado pela leitura da subseção 2.7. As contabilizações dos dados do Brasil, referentes a essa classe, incorporam essa mudança conceitual, mas, em relação aos outros países, foram mantidas conforme publicadas.

$\mathrm{Na}$ busca de referência consistente e harmônica para o trabalho, os dados desses países foram reorganizados a partir dos critérios metodológicos definidos para o Brasil. Ganharam, por essa razão, uma estruturação padrão, uma maneira unificada de cálculo e um formato comum de apresentação. Isso requereu um exaustivo esforço e um exame detalhado do conteúdo publicado para cada país, o que permitiu a identificação dos problemas já mencionados e a formulação de alternativas para corrigir os efeitos que esses problemas teriam na confiabilidade dos dados resultantes da conversão. O resultado dessa conversão apresentou um grau de fidelidade às fontes originais que pode ser considerado quase total. A exceção é para os totais do Japão que, na conversão, diminuíram em torno de 5\% em razão de erro nos dados originais, conforme apontado no item 2.9i desta seção.

\section{Análise dos resultados}

Conforme definido (seção 2.2), o escopo mais amplo do objeto de estudo em discussão é o Metabolismo Econômico-Ambiental (MEA) do Brasil e, de forma mais particular, a parte dele relacionada com suas "entradas", isto é, a Demanda Material Total (DMT), em relação ao qual buscam-se identificar aspectos relevantes a fim de relacioná-los com outras variáveis tradicionalmente utilizadas na análise da economia. Essa DMT será analisada por meio de diversos fluxos, agrupados da seguinte maneira:

116 


\section{Segundo a origem: $\quad$ Demanda Doméstica Total (DDT) \\ Demanda Importada Total (DMT) \\ Segundo a natureza: $\quad$ Demanda Reconhecida Total (DRT) \\ Demanda Ignorada Total (DlgT) \\ Destinados à exportação: Demanda Exportada Reconhecida (DER) \\ Demanda Exportada Ignorada (DEI)}

A distribuição desses fluxos pelas diversas classes (não-renováveis, renováveis, erosão de solo e material industrial sem enquadramento) e categorias de materiais, ao longo de um certo período, revelaria aspectos significativos da relação Sistema Econômico-Ambiente.

A síntese dos resultados obtida está no ANEXO 01: Síntese Integrada das Demandas Materiais do Brasil, EUA, Alemanha, Japão e Holanda e no ANEXO 02: Resumo das Características Relevantes das DMTs do Brasil, EUA, Alemanha, Japão e Holanda. Quando o foco da análise não for o período todo, o ano a ser utilizado como referência, para o Brasil, será o de 1995 e, para os demais países, 1994. O caso concreto pesquisado é o MEA do Brasil. Os MEAs dos demais países foram incluídos para servir como fontes de comparações para as análises. Serão analisadas as seguintes questões: (i) relações entre DMT, PIB e população; (ii) estrutura da DMT quanto à origem, natureza e classes dos materiais; (iii) uso de indicadores de intensidade material para avaliação da economia.

\subsection{DMT, PIB e população}

Nesta seção serão analisadas as relações entre DMT, PIB e População.

a) Qual é a relação entre o tamanho do PIB e o volume da DMT de uma economia? No caso do Brasil, a DMT é compatível com o seu PIB?

Comparando-se a relação DMT-Brasil /DMT-demais países com a relação PIB-Brasil/PIB-demais países (referente aos EUA é 0,16 e 0,13; referente à Alemanha é 0,59 e 0,57; referente à Holanda é 3,30 e 2,98; referente ao Japão é 0,80 e 0,33), verifica-se uma surpreendente similaridade entre essas relações, o que permite inferir que, com exceção do $J_{a p a ̃ o}{ }^{11}$, há uma relação direta entre o volume da DMT e o tamanho do PIB das economias consideradas (Conclusão 1). Por conseqüência, o volume da DMT do Brasil é compatível com o seu PIB.

${ }^{71}$ O PIB do Japão é três vezes maior que o do Brasil, enquanto sua DMT é apenas 1,2 vezes maior. Embora somente o Japão se situe claramente fora do padrão, a Holanda também apresenta tendência nesse sentido. Esse fato deve-se à grande dependência de matéria importada que ambos registram, como pode ser visto na seção 8.2. 
José Alberto da Costa Machado, Norbert Fenzl

b) As taxas de crescimento do PIB, no período, implicam crescimento correspondente na DMT? No caso do Brasil é possível observar essa relação?

As taxas de crescimento do PIB e DMT são: o PIB do Brasil cresceu 67,5\%, similar à DMT que foi 65,5\%, e tal similaridade foi mantida em todo o período; o PIB dos EUA cresceu 63,3\%, cinco vezes mais do que a DMT $(13,1)$, e, embora nos últimos dez anos a tendência desta tenha sido de crescimento, está claro que o PIB cresce a taxas maiores; o PIB da Alemanha cresceu 87,0\%, mais que o dobro da DMT $(42,2 \%)^{72}$; o PIB do Japão cresceu 97,2\%, quase o triplo da DMT (34,7\%), com tendência ao alargamento dessa diferença; o PIB da Holanda cresceu 52,0\%, bem próximo do crescimento da DMT $(42,5 \%)^{73}$. Essas informações permitem inferir que, com exceção do Brasil, onde o crescimento do PIB e da DMT são similares, o PIB das economias consideradas desenvolvidas cresce a taxas muito maiores do que as taxas de crescimento de sua DMT (Conclusão 2).

Também se observa que, na quase totalidade dos anos, o crescimento ou a queda dos PIBs de todos os países estudados estão acompanhados de crescimento ou queda nas suas DMTs, embora não a taxas proporcionais $^{74}$. Isso significa que a DMT de uma economia tem comportamento influenciado, mas não determinado, pelo seu PIB, já que cresce ou decresce com ele, mas não necessariamente às mesmas taxas. Embora havendo casos localizados, em que a DMT registra crescimento maior que o do PIB, o padrão geral é que este registre crescimento acumulado cada vez maior que o da DMT (Conclusão 3).

c) Existe alguma relação direta entre tamanho da população e volume da DMT?

Comparando-se as relações DMT-Brasil/DMT-demais países com População-Brasil/População-demais países (referente aos EUA é 0,16 e 0,63; referente à Alemanha é 0,59 e 2,00; referente ao Japão é 0,80 e 1,31; referente à Holanda é 3,30 e 10,60), verifica-se uma completa dessemelhança entre essas relações, o que permite inferir que não há relação direta entre o volume da DMT e o tamanho da população dos países estudados (Conclusão 4).

\footnotetext{
${ }^{72}$ Em 1991, devido à unificação das duas Alemanhas, tanto a DMT quanto o PIB registraram crescimento fora do padrão. Entretanto, para a DMT, essa dinâmica atípica apresenta-se como uma bolha, que logo arrefeceu nos anos seguintes. Já para o PIB não houve arrefecimento e o patamar alcançado após 1991 tende a continuar crescendo.

${ }^{73}$ Até 1992 a DMT acumulou um crescimento maior que o do PIB, mas após 1992 essa dinâmica inverteu-se e o PIB cresceu cerca de nove vezes mais que a DMT.

${ }^{74}$ As exceções são pontuais e podem ser conferidas diretamente nas fontes referidas.
} 
d) Existe alguma relação entre as taxas de crescimento da população com as taxas de crescimento da DMT?

Comparando-se as taxas de crescimento da População e da DMT nos diversos países (para o Brasil foi 49,9\% e 65,5\%; para os EUA foi 20,7\% e 13,1\%; para a Alemanha foi $32,0 \%$ e 42,0\%; para o Japão foi $12 \%$ e $24,7 \%$; para a Holanda foi $12,7 \%$ e $42,5 \%$ ), observa-se que não há qualquer relação entre crescimento da população e crescimento da DMT. Ademais, o padrão de variação da dinâmica populacional é quase constante, ao longo dos anos, para todos os países, enquanto a dinâmica de variação da DMT é completamente distinta desse padrão. Pode-se então, concluir que as taxas de crescimento da DMT não possuem nenhuma relação direta com as taxas de crescimento populacional (Conclusão 5).

e) Quais são as diferenças fundamentais entre as economias estudadas à luz das variáveis consideradas?

(i) Todos os países analisados apresentam a mesma relação direta entre DMT e PIB. Entretanto, no Brasil, há aspectos específicos: enquanto nos países industrializados "desenvolvidos" o PIB cresce a taxas muito superiores à DMT, no Brasil a DMT e o PIB crescem em proporções iguais. Isso indica que a economia brasileira ainda se encontra encaixada em atividades materialmente produtivas.

(ii) No Japão também o PIB e a DMT crescem juntos, entretanto, o PIB cresce em taxas muito superiores, se comparado aos países europeus e aos EUA. Isso indica que, sendo o Japão um país muito pobre em recursos naturais, ele necessita de uma eficiência energético-material muito maior do que os demais.

(iii) A demanda material das economias analisadas não demonstra nenhuma relação direta com o crescimento da população.

\subsection{Origem da DMT nas economias estudadas}

Nesta seção serão analisadas as origens da matéria demandada pelas economias estudadas.

(i) De onde vem a matéria utilizada pela economia dos países estudados? Como essa distribuição, por origem, pode influenciar sua dependência do Ambiente de outros países?

Analisando-se a participação da matéria de origem doméstica e importada na DMT dos países estudados (no Brasil é 92,3\% e 7,7\%; nos EUA é 92,3\% e 7,7\%; na Alemanha é 64,1\% e 35,9\%; no Japão é 32,7\%\% 
José Alberto da Costa Machado, Norbert Fenzl

e 67,3\%; na Holanda é 31,2\% e 68,8\%), observa-se que a matéria consumida pelo Brasil e pelos EUA é originária, quase na totalidade, do seu próprio Ambiente. A Alemanha ainda é dependente do seu próprio ambiente, mas já apresenta uma forte participação de importados. Já o Japão e a Holanda são, basicamente, dependentes de importação de matéria em uma proporção de quase 7/10. Verificando-se como a relação doméstico-importado comportou-se ao longo do período estudado, observa-se que, para o Brasil e os EUA, esse padrão de distribuição manteve-se similar, enquanto, para a Alemanha, registrou-se um padrão de relativa similaridade até 1990. A partir de 1991, ano de unificação da Alemanha Ocidental e Alemanha Oriental, esse padrão mudou para um patamar superior (girava em torno de $53 \%$ e passou a girar em torno de 64\%), o qual se manteve similar até o final do período. Para o Japão e a Holanda, a similaridade manteve-se, mas com significativa tendência de aumento dos fluxos importados.

Assim, pode-se concluir que: o Brasil e os EUA são independentes do Ambiente de outros países (Conclusão 6); a Alemanha, com a unificação, diminuiu seu nível de dependência do Ambiente de outros países, mas registra tendência para voltar aos padrões anteriores (Conclusão 7); o Japão e a Holanda são altamente dependentes do Ambiente de outros países e tendem a ampliar seus atuais níveis de dependência externa (Conclusão 8).

\subsection{Natureza da DMT nas economias estudadas}

Nesta seção buscar-se-á responder às seguintes questões: Qual é o volume de matéria que o sistema econômico desperdiça sem contabilizá-lo? Qual é a importância dessa contabilidade para a sustentabilidade da nossa relação com o Ambiente? Existem indícios de mudança nos desperdícios ignorados?

Analisando-se a participação da matéria de natureza reconhecida e de natureza ignorada na DMT dos países estudados (no Brasil é 43,1\% e 56,9\%; nos EUA é 32,2\% e 67,8\%; na Alemanha é 35,7\% e 64,3\%; no Japão é 49,2\% e 50,8\%; na Holanda é 56,0\% e 44,0\%), verifica-se que, com exceção da Holanda, os demais países têm sistemas econômicos que gastam, em desperdícios ignorados, mais de 50\% de toda a matéria que retiram do Ambiente. EUA e Alemanha consomem, nesses desperdícios, quase 7/10 de suas DMTs.

Verificando-se a evolução dessas relações durante o período estudado, pode-se constatar que: a) os EUA registraram uma taxa de desperdício material muito elevada ao longo de todo o período; b) a Alemanha e o Japão, cujas demandas ignoradas já eram altas no início do 
período, ainda registram uma tendência de crescimento nos últimos anos; c) na Holanda, embora a taxa de desperdício seja a menor de todos, a demanda ignorada está crescendo, nitidamente; d) o Brasil registrou uma dinâmica diferente dos demais países. A participação da demanda ignorada na DMT, embora ainda em patamares altos, está caindo, consistentemente, ano a ano.

As análises acima permitem concluir que, de maneira geral, a distribuição da DMT, segundo a natureza da matéria movimentada, registrada ao final do período estudado, revela uma característica persistente do MEA de cada país, mas com tendências nítidas em cada caso. Para os EUA, a tendência é manter o padrão; para a Alemanha, o Japão e a Holanda, a tendência é ampliar a participação da demanda ignorada; para o Brasil, a tendência é diminuir a participação da demanda ignorada.

Assim, em relação aos desperdícios que o sistema econômico produz e dos quais nem mesmo toma conhecimento na sua contabilidade econômica, pode-se concluir que: o s EUA e Alemanha são absolutamente refratários ao peso que representam para o Ambiente (Conclusão 9); Japão e Holanda tendem a ser cada vez mais refratários (Conclusão 10); Brasil tende, consistentemente, a ser menos refratário (Conclusão 11).

Essas conclusões evidenciam o quanto é improcedente a suposição de que o avanço tecnológico diminui a sobrecarga das economias sobre o ambiente. Os países de maior nível tecnológico são os mais refratários aos impactos que causam ao Ambiente.

\subsection{Participação das classes de materiais nas economias estudadas}

Nesta seção, buscar-se-á responder às seguintes perguntas: Qual a classe de material mais determinante nas demandas dos sistemas econômicos? O fato de existir uma classe hegemônica tem implicações para a sustentabilidade dos MEAs? Há indícios de mudança no padrão de consumo de cada classe de materiais?

A participação das classes na DMT das economias estudadas apresenta-se assim: a) no Brasil: Não-Renováveis 28,9\%, Renováveis 36,6\%, Erosão de Solo 33,4\% e Material Industrial Sem Enquadramento 1,0\%; b) nos EUA: Não-Renováveis 72,3\%, Renováveis 8,2\%, Erosão de Solo 17,6\% e Material Industrial Sem Enquadramento 1,9\%; c) na Alemanha: NãoRenováveis 76,7\%, Renováveis 6,8\%, Erosão de Solo 2,4\% e Material Industrial Sem Enquadramento 14,1\%; d) no Japão: Não-Renováveis 88,1\%, Renováveis 6,4\%, Erosão de Solo 4,0\% e Material Industrial Sem Enquadramento 1,5\%; e) na Holanda: Não-Renováveis 52,0\%, Renováveis 29,9\%, Erosão de Solo 0,1\% e Material Industrializado Sem Enquadra- 
José Alberto da Costa Machado, Norbert Fenzl

mento 18,0\%. Essas informações indicam que: f) com exceção do Brasil, os demais países possuem DMTs que são compostas, hegemonicamente, pela classe Não-Renováveis - nos EUA e na Alemanha, essa participação ultrapassa 7/10 da DMT e, no Japão, chega a ser quase 9/10 de toda a DMT; g) Brasil e Holanda registram uma alta participação da classe Renováveis - no Brasil, essa classe é a de maior participação em sua DMT, chegando a quase 4/10; h) Brasil e EUA registram uma alta participação da classe Erosão de Solo - no Brasil, essa classe chega a 1/3 da sua DMT; i) Alemanha e Holanda registram uma significativa participação da classe Material Industrializado sem Enquadramento.

Analisando-se essas distribuições ao longo do período estudado, podem fazer as seguintes observações.

j) Em relação à classe Não-Renováveis: no Brasil, a participação quase duplicou, mudando de 15,6\% para 28,9\%; nos EUA, o padrão é similar, mas continuamente crescente; na Alemanha, embora haja uma tendência decrescente até 1988, o período terminou com padrão similar ao do início; no Japão, o padrão é similar, com tendência ainda crescente; na Holanda, os padrões mudaram para patamares bem menores (de 70,0\% para 52,0\%). k) Em relação à classe Renováveis: exceto a Holanda, que mudou de 20,99\% para 29,75\%, com tendência crescente, todos os demais países mantiveram padrão similar. l) Em relação à classe Erosão de Solo: houve mudança de padrão para patamares menores e com tendência a decrescer para o Brasil (de 46,70\% para 33,4\%) e EUA (de 30,78\% para 17,65\%); Alemanha, Japão e Holanda mantiveram o padrão. m) Em relação à classe Material Industrializado sem Enquadramento: com exceção da Alemanha e da Holanda, que registraram uma pequena tendência de crescimento, todos os demais mantiveram o padrão.

Esses dados permitem concluir que: todos os países industrializados do estudo possuem uma DMT composta, hegemonicamente, pela classe Não-Renováveis (Conclusão 12); com exceção da Holanda, que tende a inverter os padrões de participação das classes Não-Renováveis e Renováveis, todos os países considerados tendem a ampliar, ainda mais, a participação de materiais não-renováveis em suas DMTs (Conclusão 13); O Brasil, de forma consistente e a passos largos, tende a assumir padrões similares ao dos EUA, Alemanha e Japão (Conclusão 14).

Constata-se, assim, que as economias desenvolvidas são, estruturalmente, comprometidas com materiais não-renováveis. Isso indica a continuação dos padrões atuais de exploração desses recursos e a continuidade dos problemas ambientais decorrentes do uso deles. O Brasil caminha para o mesmo padrão, e somente a Holanda parece seguir novos caminhos. 


\subsection{Avaliação das economias com indicadores de intensidade material}

Os países são diferentes em extensão territorial, em tamanho da população, em grau de industrialização, em nível de vida de sua população e em outras tantas características. Comparar suas economias apenas pelo valor total de seus PIBs e de suas DMTs não pode revelar, realmente, se há semelhanças ou diferenças ${ }^{75}$ entre elas. Assim, para que as demandas materiais dos países possam ser comparadas, são necessários indicadores que não se distorçam em face dessas diferenças. Nesta seção serão propostos dois indicadores com essa natureza e, em seguida, serão testados quanto às potencialidades que portam. São eles: DMT por unidade de PIB - relação entre o total da matéria demandada pela economia de um país e o seu PIB, que revela a intensidade material do PIB, isto é, a quantidade de matéria embutida em cada unidade do PIB (tons de matéria por milhão de dólares); DMT per capita - relação entre o total de matéria demandada pela economia de um país e a sua população, que revela a quantidade de matéria que aquele sistema econômico consome por cada membro da sua população (tons de matéria por pessoa).

\subsubsection{A DMT por unidade do PIB}

Analisando-se quantas toneladas de matéria representa cada milhão de PIB nos países estudados (no Brasil são 5.104, e esse volume não sofreu alteração em relação ao início do período; nos EUA são 4.001, e esse volume é 30,7\% menor do que era no início do período; na Alemanha são 4.875, e esse volume é 23,9\% menor do que era no início do período; no Japão são 2.097, e esse volume é 31,7\% menor do que era no início do período; na Holanda são 4.599, e esse volume é 6,2\% menor do que era no início do período), pode-se concluir que, com exceção do Brasil, que teve variação zero, e a Holanda com variação mínima, o PIB dos países estudados perderam intensidade material no período e tendem a continuar perdendo (Conclusão 15).

Essa conclusão é consistente com a constatação já feita (Conclusão 2) de que o PIB pode crescer a taxas muito superiores à DMT de suas economias. Possivelmente isso se deve, em parte, ao fato de que, nos últimos tempos, boa parte do PIB dos países estudados veio do setor de serviços, portanto, não associados a fluxos físicos de matéria. Apesar de não ser objeto desta pesquisa, desconfia-se que esse fenô-

\footnotetext{
${ }^{75}$ Por exemplo: a Alemanha tem um PIB 5,2 vezes maior que o da Holanda, mas ambos os países possuem graus similares de industrialização e de nível de vida. Já o Brasil possui um PIB mais de 3 vezes superior ao da Holanda, porém, em termos de nível de vida de suas população, os dois países são absolutamente distintos.
} 
José Alberto da Costa Machado, Norbert Fenzl

meno seja causado, sobretudo, pelo efeito da descapitalização dos setores materialmente produtivos em favor do inchamento da especulação financeira. Esse assunto mereceria ser estudado com maior atenção.

\subsubsection{A DMT per capita}

O consumo, em toneladas de matéria, que cada economia registra por membro de sua população é o seguinte: no Brasil, é 19,85, tendo crescido 11,7\% no período; nos EUA, é 74,07, tendo decrescido 6,3\% no período; na Alemanha, é 66,31, tendo crescido 7,7\% no período; no Japão, é 32,16, tendo crescido 20,2\% no período; na Holanda, é 66,69, tendo crescido $26,4 \%$ no período.

Examinando o período todo, observa-se que a tendência geral desse indicador, em todos os países, é crescente. Até os EUA, que apresentaram um decréscimo global de 6,3\% no período, mostram uma tendência de crescimento a partir de 1983. Isso permite concluir que em todos os países a DMT per capita aumentou. Considerando que ao mesmo tempo há um crescimento populacional real, em termos globais, a intensidade material das economias aumentou (Conclusão 16).

\subsubsection{A DMT absoluta e a DMT per capita}

Nesta seção serão analisados os graus de crescimento que os diversos fluxos materiais dos países estudados sofreram no período considerado. Serão considerados por classe de material e, dentro de cada classe, a variação absoluta e per capita. Para essa análise serão considerados os seguintes padrões para os graus de crescimento: crescimento superintenso (>60\%); crescimento intenso (20 a 60\%); crescimento moderado (5 a 20\%); crescimento estabilizado (-5 a +5\%); declínio moderado (-5 a -20\%); declínio intenso (-20 a -60\%); declínio superintenso $(<-60 \%)$.

a) Em termos absolutos: i) as DMTs de todos os países, com exceção dos EUA que registraram crescimento moderado, tiveram crescimento intenso ou superintenso; ii) todos os fluxos componentes dessas DMTs, segundo a origem ou segundo a natureza, de todos os países, também cresceram de forma intensa ou superintensa - as exceções são os fluxos domésticos dos EUA, Japão e Holanda, os fluxos ignorados dos EUA, que cresceram de forma apenas moderada, e os fluxos importados da Alemanha, que se mantiveram estáveis no período analisado; iii) em relação às classes, com exceção do declínio intenso nos fluxos de Erosão de Solo dos EUA e nos fluxos importados de NãoRenováveis da Alemanha, e do declínio moderado dos fluxos 
ignorados de Renováveis e dos fluxos domésticos do Japão, todos os demais fluxos, de todas as classes e em todos os países, apresentam crescimento em suas demandas - em quase todos os casos o grau desse crescimento foi intenso ou superintenso.

b) Em termos per capita: i) em relação ao total da demanda, mesmo considerando o aumento populacional de cada país, que tende a ofuscar o crescimento absoluto da DMT, só houve declínio desse indicador para os EUA, embora, como foi analisado em 3.5.2, mesmo nesse país, a tendência desse indicador, nos últimos 10 anos, seja de crescimento; ii) em relação aos demais fluxos, segundo a origem ou segundo a natureza, e mesmo considerando o efeito do crescimento populacional já tratado anteriormente, verifica-se que somente houve declínio para os fluxos ignorados do Brasil, para os fluxos domésticos e ignorados dos EUA (mas com tendência de crescimento nos últimos 10 anos) e para os fluxos importados da Alemanha; iii) em relação às classes, só houve declínio na demanda per capita de Erosão de Solo do Brasil e dos EUA e de Não-Renováveis da Holanda.

Das análises acima se pode concluir que os sistemas econômicos dos países estudados continuam crescendo em suas demandas totais por matéria, seja em termos absolutos, seja em termos per capita. Esse crescimento, na maioria dos casos, se dá de forma intensa ou superintensa, sejam os seus fluxos considerados segundo a origem ou segundo a natureza. Exceções pontuais existem apenas em função de um declínio acentuado em Erosão de Solo para o Brasil e para os EUA e no fluxo de importados de Não-Renováveis da Alemanha (Conclusão 17).

Em relação à magnitude da DMT per capita, constata-se que, no Brasil, cada um dos seus habitantes representa, para o Ambiente, uma demanda anual de 19.850 quilos de matéria ou 284 vezes o peso de uma pessoa adulta. Nos EUA, cada habitante representa uma demanda de 74.070 quilos ou 1.058 vezes o peso de uma pessoa adulta (um americano pesa, para o Ambiente, 3,73 vezes mais do que um brasileiro). Na Alemanha, cada habitante representa uma demanda de 66.310 quilos ou 947 vezes o peso de uma pessoa adulta (um alemão pesa, para o Ambiente, 3,34 vezes mais do que um brasileiro). No Japão, cada habitante representa uma demanda de 32.160 quilos ou 459 vezes o peso de uma pessoa adulta (um japonês pesa, para o Ambiente, 1,62 vezes mais do que um brasileiro). Na Holanda, cada habitante representa uma demanda de 63.690 quilos ou 910 vezes o peso de uma pessoa adulta (um holandês pesa, para o Ambiente, 3,21 vezes mais do que um brasileiro). 
José Alberto da Costa Machado, Norbert Fenzl

\section{Conclusões, relevância e recomendações}

\subsection{Principais constatações}

As economias estudadas retiram do Ambiente, anualmente, 33 bilhões de toneladas de matéria. Se considerarmos a média per capita do estudo e a extrapolarmos para a população mundial, chegaremos à conclusão de que as sociedades humanas, em conjunto, retiram do ambiente planetário, anualmente, 306 bilhões de toneladas de matéria ${ }^{76}$. Se tomarmos por base o maior consumo per capita do estudo - o dos EUA -, serão 444 bilhões de toneladas; se considerarmos o menor - o do Brasil - ainda teremos a astronômica cifra de 119 bilhões de toneladas anuais. O mais grave desses resultados é que, do total da matéria demandada pelas economias estudadas, 23 bilhões de toneladas são da classe não-renováveis. Se for feita a mesma extrapolação anterior, concluiremos que as sociedades em conjunto retiram do ambiente 216 bilhões de toneladas de matéria não-renovável. Se tomarmos por base a maior demanda per capita de matéria não renovável - a dos EUA (53,57 tons) - serão 321 bilhões toneladas; se considerarmos a menor - a do Brasil (5,74 tons) -, serão 35 bilhões de toneladas ${ }^{77}$. Isso é grave porque, além de expressar uma descomunal taxa de esgotamento dos recursos não-renováveis do planeta, indica que esse volume de matéria, após o uso, transforma-se em lixo e, por isso, em fonte de entropia.

Embora não haja informações seguras sobre a perda de solo para alguns países do estudo, só os EUA e o Brasil juntos (para os quais os dados são consistentes) perderam 4,5 bilhões de toneladas da capa de seus solos. Esse impressionante volume de matéria perdida com a erosão leva a reboque a fertilidade local e converte-se em razão básica do assoreamento dos rios.

Pode o planeta suportar tamanho impacto antrópico? É possível estender para todas as nações esse modelo de desenvolvimento que é tão demandante do Ambiente? Se um impacto antrópico dessa grandeza vem ocorrendo anualmente, como é possível medir seus efeitos acumulados?

Foi visto que as economias têm esse padrão tão consumidor de matéria porque é da natureza do Sistema Econômico, está implícito na sua lógica de funcionamento, por isso é difícil supor que o próprio siste-

\footnotetext{
${ }^{76}$ A projeção foi feita considerando-se a população mundial de 6 bilhões de habitantes e a média per capita do estudo de 51 tons Obviamente essa estimativa é apenas hipotética, já que esse consumo material foi obtido com base em países industrializados e apenas o Brasil é do grupo de países em desenvolvimento. Entretanto, a extrapolação está sendo feita porque esses países industrializados são os "modelos" de todos os demais, e o padrão de consumo que se verifica neles é tido como a meta de todas as políticas de desenvolvimento dos países do mundo.

${ }^{77}$ Essa, certamente, é uma estimativa muito baixa e irreal, porque somente em relação aos países estudados já são 23 bilhões.
} 
ma se autocorrija, como alegam os defensores da capacidade do mercado em regular as questões ambientais. Ademais, outras questões contrapõem-se a essa possibilidade: a) o Sistema Econômico só avalia a eficiência de suas dinâmicas em bases monetárias, o que o impede de perceber o seu custo para o Ambiente; b) o PIB, embora não consiga visibilizar a matéria que movimenta, parece ser o principal motor do aumento de suas demandas - assim, com o aumento do PIB, principal meta de política econômica dos países, o que é aumento de riqueza para o Sistema Econômico é empobrecimento para o ambiente; $c$ ) a maior parte da matéria movimentada pelo Sistema Econômica é de natureza ignorada (Brasil 56,9\%, EUA 67,8\%, Alemanha 64,3\%, Japão 50,8 e Holanda 44,0\%). Trata-se daquela matéria que é movimentada antes de o recurso natural entrar no circuito econômico. Isso significa que o Sistema Econômico não tem sensores capazes de detectar esse desperdício e, por isso, também não pode atuar para minimizá-lo, já que para ele essa matéria não existe.

Ou seja, se o Sistema Econômico é deixado ao sabor de suas dinâmicas próprias, a tendência é a exacerbação dos padrões encontrados na pesquisa. Sem restrições de acesso, sejam físicas, legais ou culturais, essa volúpia consumidora de matéria não muda. Nesses vinte anos de debate sobre a sustentabilidade, de programas de pesquisa, de conferências políticas, de militância organizada, etc., o que se vê é que o Sistema Econômico seguiu seu curso. Não diminuiu o seu ímpeto consumidor em relação ao Ambiente e, ao contrário disso, aumentou-o ainda mais.

Portanto, é necessário buscar uma outra forma de medir a eficiência dos processos econômicos. É preciso internalizar no sistema a "consciência" dos fluxos físicos movimentados pelos fluxos monetários da economia. Para fazer isso, é preciso medir, e, nesse particular, a metodologia utilizada revelou-se potente em trazer à tona as particularidades e características das demandas materiais do Sistema Econômico. Seus resultados permitem a construção de indicadores simples como a Demanda Material por Unidade do PIB e a Demanda Material Per Capita. Esses indicadores, calculados para as diversas classes de materiais, para os diversos setores da economia, para as diversas naturezas de matéria movimentada, etc, possibilitariam a avaliação e o monitoramento da intensidade material das economias.

O trabalho também revelou que o PIB do Brasil, embora ainda encaixado na demanda material, reflete um Sistema Econômico de mesma natureza dos demais e caminha, a passos largos, para assumir o mesmo perfil, isto é: perdulário no uso, gigantesco e refratário no desperdício e intenso na utilização de matéria não-renovável. Entretanto, o 


\section{José Alberto da Costa Machado, Norbert Fenzl}

Brasil ainda não possui uma estrutura completamente comprometida com esse perfil, já que 36,6\% da matéria que ele consome é de recursos renováveis. Talvez por isso suas perdas de solo, mesmo calculadas de maneira conservadora, sejam extremamente altas $(33,4 \%)$ e apontam um grave foco de problema na agenda ambiental brasileira. Porém, o fato de 1/3 das demandas materiais da economia brasileira ser de recursos renováveis não garante que as formas de uso e acesso a esses recursos sejam sustentáveis ao longo do tempo. Mas ele é o país que reúne melhores condições para transformar a base do seu Metabolismo Econômico-Ambiental para recursos sustentáveis, candidatando-se a ser o projeto-piloto para uma futura civilização de biomassa (a Holanda também, mas depende muito de importação). Ademais, diferentemente do que ocorre em outros países, a participação da mochila ecológica (matéria ignorada) na DMT da economia brasileira, tem diminuído a cada ano.

\subsection{Relevância política}

\subsubsection{Foco novo para análise}

O projeto técnico-científico da modernidade apresentou, no final do século XVIII, com a Revolução Industrial, os alicerces de um novo modo de produção, um novo estilo de vida e, por conseguinte, um novo modo de relação com o ambiente natural. O espírito econômico baseado no capitalismo industrial, hoje globalizado, é o vetor onipotente dos destinos da civilização. Todas as nações desejam adotá-lo e perseguem-no como única salvação para seus cidadãos. O modelo de desenvolvimento surgido dessa matriz converte-se em única expectativa a ser buscada a qualquer custo.

Há indícios de que novos paradigmas para a ciência e para a vida começam a emergir ${ }^{78}$. Entretanto, a disseminação de novos valores capazes de reconfigurar toda a relação da Sociedade-Ambiente não acontece de imediato, sobretudo quando a experiência cotidiana não aponta a necessidade de mudanças em seu estilo de vida ${ }^{79}$. Além disso, longe de causar repulsa, o modo de produção e o estilo de vida das sociedades industriais representam um modelo que os países subdesenvolvidos e

\footnotetext{
${ }^{78}$ Vide LUBCHENCO (1998), que analisa as inquietudes com o papel da ciência nos atuais impasses do modelo de desenvolvimento vigente e as demandas dos cientistas por um novo pacto social para ela.

${ }^{79}$ Ao contrário do que aconteceu com as sociedades de caçadores e coletores e com as sociedades agrícolas, que efetivamente experimentaram efeitos danosos toda vez que suas necessidades ultrapassaram as possibilidades ambientais, a sociedade industrial dos dias atuais registra o contínuo barateamento dos recursos naturais, o permanente aumento na oferta de produtos agrícolas, o alargamento do tempo e da qualidade de vida, a constante inovação tecnológica para sustentar consumos crescentes e a desconexão da manutenção de seu MEA de suas bases territoriais por poderem obter e transportar, de qualquer distância e a preços baixos, os recursos necessários para tal. Essas circunstâncias ofuscam a natureza intrínseca do modo de produção expressado pelo capitalismo industrial e propiciam à sociedade a sensação de viver no "melhor dos mundos".
} 
em desenvolvimento tudo fazem para imitar ${ }^{80}$. E isso representa o grande impasse da atualidade. Mas, é possível estender esse modo de produção e estilo de vida a todos os recantos do planeta? Pode o ambiente natural planetário continuar funcionando com os mesmos padrões que até agora garantiram a sobrevivência da civilização se essa forma de relação Sociedade-Ambiente globalizar-se? Há indícios de que isso parece não ser possível. Então, a busca de modos de produção mais sustentáveis requer esforço no sentido de convencer a sociedade, especialmente seus âmbitos de formulações econômicas e políticas, de que existem fatos concretos que apontam o esgotamento dos modelos vigentes e colocam em risco sua própria sobrevivência.

Mas, se os indicadores que registram a performance da sociedade industrial apontam resultados positivos que reforçam os atrativos do industrialismo-capitalista, é necessário que sejam produzidas informações de outra natureza, capazes de tornar visíveis os fatores nocivos. Nesse contexto insere-se a relevância da abordagem apresentada neste trabalho. É que, trazendo à tona o verdadeiro peso dos diversos processos socioeconômicos sobre o Ambiente, a Sociedade terá condições de redirecionar, de forma consciente, os rumos do seu atual padrão de interação com o meio, antes que esse meio, ajustando-se às interferências produzidas pela sociedade, mude seu padrão de funcionamento e inviabilize a civilização.

\subsubsection{Base para políticas públicas}

As propostas no sentido de minimizar a nocividade das atividades socioeconômicas em relação ao Ambiente quase sempre se baseiam em justificativas éticas, em desejos políticos ou em convicções ideológicas, todas representando generosas intenções, mas sem poder de convencimento sobre a sociedade, exatamente porque desacompanhadas de informações que realmente visibilizem, em linguagem legitimada por todos, o verdadeiro peso da economia sobre o Ambiente. Nessa perspectiva, a produção de indicadores, como os tratados aqui, representa um avanço na abordagem da sustentabilidade e, de maneira mais específica, a medição do fluxo energético-material do MEA possibilita a viabilização imediata de políticas potencialmente capazes de reverter as in-

${ }^{80}$ LIMA (1997:2) considera que não há expectativa de se abdicar do estilo de vida, das comodidades e dos avanços técnicocientíficos que a modernidade propiciou em favor de caminhos em que essas conquistas tenham que ser recusadas. Assim se refere: "não se concebe (...) [as] poucas sociedades sustentáveis conhecidas serem consideradas exemplos para as sociedades desenvolvidas seguirem, ou de um chefe Kaiapó prestando consultoria em um Ministério Europeu. Estamos longe de ter uma postura totalmente desencantada com os resultados da industrialização". 
José Alberto da Costa Machado, Norbert Fenzl

terferências danosas sobre o Ambiente. Alguns exemplos dessas políticas são apresentados abaixo.

a) Políticas tributárias com base de cálculo em matéria e energia

A maioria das alternativas de tributação sobre os processos socioeconômicos e sobre os produtos por eles gerados toma por base de cálculo os valores monetários, ainda que taxas diferentes sejam adotadas para processos e produtos diferentes. Essa via de tributação não considera o peso desses processos e produtos em relação ao Ambiente e, por isso, pouco efeito tem na demanda material da economia.

Políticas de tributação que tomassem por base de cálculo a quantidade de matéria e energia embutidas e usadas nos produtos e processos econômicos certamente tenderiam a refletir-se nos preços dos produtos, melhor expressando seus pesos em relação ao Ambiente. Ademais, por influenciarem diretamente os preços, as considerações sobre o consumo energético-material tornar-se-iam permanentes na agenda da sociedade, ensejando, assim, uma visão mais clara da verdadeira dimensão do MEA.

Ainda como decorrência de políticas dessa natureza, seria possível regular, com taxações diferenciadas, recursos naturais sobreexplorados ou em vias de extinção, situações que nem sempre o mercado é capaz de regular porque este se baseia na oferta já em circulação e não na situação de suas fontes de reserva.

\section{b) Políticas para intensificação do uso do trabalho humano}

Por variadas razões, que não serão analisadas aqui, a produção industrial tende, cada vez mais, a minimizar o fator trabalho como componente de seus custos. Isso ocorre porque, à medida que a sociedade avança na conquista de direitos, esse fator aumenta seu peso tanto por conta do seu preço em si mesmo quanto por conta de tributos baseados na folha de pagamento das empresas. Por outro lado, os recursos naturais embutidos nos produtos e utilizados pelos processos econômicos que os geram tendem a ficar mais baratos, em razão da competição globalizada que se acirra cada vez mais por meio do rebaixamento de preços, da formação de oligopólios que controlam os grandes fluxos globais e, também, da própria insuficiência do mercado em refletir a superexploração ou o esgotamento dos recursos. Então, a constante tendência do capitalismo-industrial é diminuir custos com mão-de-obra e fazer seus produtos intensivos em matéria, energia e tecnologia, sendo que essa sempre no sentido de viabilizar a eliminação do trabalho. 
Políticas no sentido de desonerar o valor dos salários de qualquer tipo de tributo e de onerar apenas a parte material-energética embutida nos produtos e usada nos processos econômicos que a geram, certamente tenderão a reformar o sistema produtivo, fazendo-o mais intensivo em mão-de-obra e menos em matéria e energia. As vantagens são significativas não somente porque isso enseja a diminuição na pressão sobre o Ambiente, mas também porque geraria mais empregos e estimularia a demanda por tecnologias mais consumidoras de força humana e menos dependente de matéria e energia.

\section{c) Políticas em relação ao mercado}

Essa abordagem também possibilita o tratamento da questão relacionada com a tirania do mercado, enquanto entidade hegemônica na regulação dos processos econômicos. É que, sendo esse mercado fundamentado em valores monetários, qualquer iniciativa dos governos para regulá-lo acaba também por basear-se em variáveis que são, direta ou indiretamente, dependentes dos valores monetários. Como os mecanismos do mercado atuam com independência e autonomia sobre esse valor monetário, o poder de interferência desses governos está sempre a reboque das dinâmicas engendradas pelos mercados. Assim, variáveis diferentes, sobre as quais possam ser estabelecidas políticas de regulação, possibilitam aos governos uma via efetiva para correção de imperfeições no funcionamento do mercado. Considerando que o enfoque apresentado enseja um outro tipo de unidade para expressar os processos e os produtos que compõem a economia, unidade essa independente de mercado, os Estados passam a ter uma alternativa consistente para retomaro papel que lhes cabe na sua regulação.

\section{d) Políticas de investimentos}

O completo conhecimento do MEA traz à tona a intensidade material de cada setor da economia, permitindo redimensionar investimentos e incentivos para aqueles setores que apresentem menos danos ao Ambiente. Isso possibilita controlar as externalidades ambientais no ponto inicial do ciclo produção-circulação-consumo, evitando-se o surgimento de efeitos indesejáveis pela prevenção em vez da remediação.

Trata-se, portanto, de uma alternativa que não traz, a priori, oposição ao crescimento econômico em si. As limitações demonstradas como necessárias são de natureza física, isto é, relacionadas com a intensidade material da economia. Ao contrário, essa alternativa sugere mesmo a possibilidade de perspectivas novas para a questão do desenvolvimento econômico, pois que acena com a intensificação do uso de força hu- 


\section{José Alberto da Costa Machado, Norbert Fenzl}

mana nos processos produtivos, e isso significa criar mercado de trabalho e, por conseqüência, mercado de consumo.

\subsection{Utilidade para a Amazônia}

As questões acerca do desenvolvimento na Amazônia são, na realidade, fruto do modelo de desenvolvimento que se globalizou como padrão. Discuti-las requer, primariamente, discutir os valores intrínsecos desse modelo, pois ele é a fonte das dinâmicas econômicas que se efetivam na região ${ }^{81}$. De fato, a história regional está marcada por sucessivas ondas $^{82}$ com o objetivo de adequá-la aos requisitos desse modelo. Assim, as mazelas sociais e os impasses ecológicos que se registram na Amazônia são expressões implícitas na natureza do projeto global do capitalismo industrial, como modelo econômico ${ }^{83}$.

Mas identificar uma matriz externa para os dilemas da Amazônia não implica recusá-los como ilegítimos ou alienígenas, porque, desejando ou não, concordando ou não, os amazônidas são parte desse projeto global e por ele foram configurados em seus valores, aspirações e cultura. Não há expectativa de se abdicar do estilo de vida, das comodidades e dos avanços técnico-científicos que a modernidade propiciou em favor de caminhos em que essas conquistas tenham que ser recusadas ${ }^{84}$.

Isso não significa negar importância ao que é exclusivamente regional, mas reconhecer que existem dinâmicas cujas potências-gênese são pressupostos de padrões de desenvolvimento que a civilização estatuiu como modelares. Ignorar essas circunstâncias é deixar de lado o que é essencial - os modelos-matrizes que a civilização legitimou como base de seus projetos, crenças e valores - e ocupar-se com o que, sendo apenas regional, é, por isso mesmo, periférico.

A questão do desenvolvimento sustentável insere-se nesse contexto. Refletindo o novo ideário surgido das inquietudes com as quais o mundo industrializado examina sua própria trajetória em relação à natureza, esse debate inseriu-se na agenda da região como nova e incon-

\footnotetext{
${ }^{81}$ MENDES e SACHS (1997:4), ao discutirem as questões que permeiam a problemática do desenvolvimento amazônico consideram: "O que está em crise, vale dizer: em julgamento, é o modelo de civilização prevalecente no mundo. (...) Na verdade, é essa própria ambiência cultural que assume o centro da cena, a cultura entendida, aqui, como a síntese do próprio conhecimento que a sociedade humana assimila sobre o seu meio e as inter-relações com ele".

${ }^{82}$ MENDES e SACHS (1997:1) referem-se às seguintes ondas: exploração das drogas do sertão, extração de matérias-primas industriais, solução para excedentes populacionais de outras regiões, motivações ecológicas, interesses geopolíticos de desnacionalização, etc.

${ }^{83}$ BRUSEKE (1996:120) refere-se à questão da seguinte forma: "É o próprio desenvolvimento do projeto global do industrialismo, seja na sua variante fordista ou pós-fordista, que gera desequilíbrios ecológicos, econômicos e sociais de maneira mais diversificada. Uma teoria do subdesenvolvimento é, necessariamente, uma teoria do desenvolvimento global".

${ }^{84}$ Como pondera LIMA (1997:2), "não se concebe (...) [as] poucas sociedades sustentáveis conhecidas serem consideradas exemplos para as sociedades desenvolvidas seguirem, ou de um chefe Kaiapó prestando consultoria em um Ministério Europeu. Estamos longe de ter uma postura totalmente desencantada com os resultados da industrialização".
} 
trolável onda a permear toda e qualquer discussão sobre os destinos da região. Sob o guarda-chuva do seu conceito, todos advogam espaço para seus interesses: governo e sociedade civil, madeireiros e extrativistas, a grande empresa agrícola e a produção familiar, a nação brasileira e a comunidade internacional, etc. Todos argüindo a legitimidade daquilo que entendem como desenvolvimento sustentável e buscando hegemonia para as ações que desenvolvem para concretizá-lo.

Mas, o que é mesmo desenvolvimento sustentável e como concretizá-lo? Essa talvez seja a principal pergunta com a qual este trabalho se ocupou. Entretanto, ao buscar responder a essa pergunta, tomou por foco fatores que não são exclusivamente regionais, mas inerentes à forma de avaliar a eficiência das economias, de uma forma geral, tal como legitimada pelo ideário econômico das sociedades industrializadas. Por isso a metodologia proposta foi testada em economias nacionais, como ponte para legitimar seu futuro emprego em economias regionais, isto é, na Amazônia. Somente em nível nacional existem informações suficientes para determinar a consistência dos fundamentos metodológicos empregados e para permitir comparações internacionais. Trata-se, portanto, de um passo inicial visando transformar a metodologia em ferramenta útil e reconhecida, para que possa ser utilizada, a posteriori, na análise da economia amazônica.

Há expectativas de que seu emprego, na Amazônia, revele aspectos políticos importantes para o desenvolvimento da região. É que ela é fonte de fornecimento de vários dos materiais que registraram maior demanda nos resultados da pesquisa, como, por exemplo, o ferro, a bauxita, a madeira, etc. Aplicando-se a metodologia à Amazônia, vai ser possível conhecer a carga ambiental que ela suporta para beneficiar outras regiões do país e do mundo. Talvez assim seja possível comprovar que a Amazônia não tem sido um problema para o Brasil e para o mundo, o mundo e o Brasil é que têm sido problema para a Amazônia.

\subsection{Recomendações finais}

A metodologia proposta e testada permitiu um olhar completamente diferente para a relação Sistema Econômico-Ambiente. E esse novo olhar revelou uma agenda nova de pesquisas tanto para o aperfeiçoamento da metodologia quanto para a aplicação dos seus enfoques a outros estudos e mesmo para a ampliação do uso dos dados levantados para este trabalho. Agrupando-os, podem ser relacionados os seguintes:

- É necessário conhecer como se dá a demanda material por regiões geográficas do Brasil e o papel que cada uma tem como importadora ou exportadora de matéria para as outras regiões. Uma pesquisa assim é particularmente útil para conhecer o papel 
José Alberto da Costa Machado, Norbert Fenzl

da Amazônia como base material do metabolismo de outras regiões.

- É necessário conhecer as relações de troca entre os países, mas com base em matéria. Uma pesquisa assim revelaria as variações no valor monetário das matérias comercializadas e traria à tona as assimetrias existentes. Também revelaria quais nações constroem seu desenvolvimento à custa do ambiente de outras.

- É necessário conhecer o que tem causado a diminuição da intensidade material do PIB, já que o volume de matéria demandada continuou a crescer. Uma pesquisa assim revelaria o papel da tecnologia, do setor de serviços, mas, sobretudo, o papel da especulação financeira nessa "desmaterialização fictícia" da economia.

- É necessário conhecer a demanda material por setor da economia. Isso revelaria a relação de dependência de um setor em relação aos outros, gerando uma espécie de Matriz Material de Insumo-Produto.

- É necessário experimentar a metodologia para níveis de cidade, comunidade e para processos da microeconomia. Neste último caso, surgiria a possibilidade da medição do Metabolismo Econômico-Ambiental de empresas e de outras organizações menores.

- São necessários estudos para definir padrões internacionais para a metodologia. Estudos dessa natureza podem propiciar um referencial comum para a classificação dos materiais, dos tipos de fluxos, dos estágios em que os materiais podem ser contabilizados, dos agregados macroeconômicos, das fontes de dados, dos modelos de relatórios, dos indicadores a serem gerados, etc.

- São necessários estudos para definir formas de agregar as informações sobre fluxo de matéria nas estatísticas nacionais, regularmente realizadas. Essa providência proveria bases para pesquisas mais sistemáticas e completas sobre o Metabolismo Econômico-Ambiental.

- São necessários estudos para definir o perfil completo de cada material, isto é, os atributos que o caracterizam enquanto elemento integrante do fluxo material. Esses estudos permitiriam definir as taxas para calcular a demanda ignorada, a origem das importações e o destino das exportações com suas respectivas taxas da demanda ignorada, os estágios nos quais os materiais transitam no Sistema Econômico, etc. 
Até agora, com exceção de esforços missionários localizados, o debate sobre a sustentabilidade da relação Sociedade-Ambiente tem registrado um grande desfile de generosas intenções e uma grande movimentação política de militâncias organizadas e agências internacionais de desenvolvimento, embora o comprometimento de todos com o ideário do desenvolvimento sustentável tenha sido pouco operacionalizado em face da ausência de alternativas consistentes para tal. O trabalho que agora se encerra foi uma tentativa de contribuir para a superação desse obstáculo. 


\section{Referências bibliográficas}

ADRIAANSE, A. et al. Resource flows: The material basis of Economies. Washington: World Resources Institute, 1997. 66p.

ALIER, J. M. Curso de Economia Ecológica. Barcelona: Universidad Autónoma, 1996.

BERTALANFFY, L. von. Teoria geral de sistemas: aplicação à psicologia. In: Teoria dos Sistemas. Tradução de Maria da Graça Lustosa Becskeházy. Rio de Janeiro: Editora da Fundação Getúlio Vargas, 1976. p.143. p.1-20.

BERTOLONI, J; LOMBARDI NETO, F. Conservação do Solo. São Paulo: Ed. ICONE. 1990. 392p.

BOSSEL, H. 20/20 Vision: Explorations of Sustainable Futures (Draft version 2.0). Kassel: Germany : Center for Environmental Systems Research, 1996.

BRITO, D. C. A paradoxal unidade do discurso do desenvolvimento. Belém: Universidade Federal do Pará / Núcleo de Altos Estudos Amazônicos. 1997. Texto para discussão interna no Doutorado em Desenvolvimento Sustentável do Trópico Úmido.

BRÜSEKE, F. J. A lógica da decadência: desestruturação sócio-econômica, o problema da anomia e o desenvolvimento sustentável. Apresentação de Octavio Ianni. Belém: Cejup, 1996. 327p.

BRUYN, S.; DRUNDEN, M. Sustainability and Indicators in Amazonia: conceptual framework for use in Amazonia. Amsterdam: Institute for Environmental Studies, 1999. (Amazonia 21 Project. A discussion document).

CARNEIRO, A. de S. Evolução dos principais componentes da oferta de carne bovina e bufalina em Belém. Belém: Comissão Estadual de Planejamento Agrícola do Pará / Convênio Ministério Agricultura / SUDAM / Governo Estado do Pará-EMATER-PA, 1981 (Série Planejamento, n. 5).

COMISSÃO MUNDIAL SOBRE MEIO AMBIENTE E DESENVOLVIMENTO. Nosso futuro comum. 2. ed. Rio de Janeiro: Editora da Fundação Getúlio Vargas, 1991. 430p.

CONSTANZA, R. et alii. The value of the world's ecosystem services and natural capital. Nature, v. 387, p. 253-260, 15 maio 1997.

136 
DNPM (Departamento Nacional de Produção Mineral). Anuário Mineral Brasileiro (AMB). Brasília: DNPM/ Ministério das Minas e Energia, 1976-96.

DNPM (Departamento Nacional de Produção Mineral). Esclarecimentos conceituais sobre a metodologia de apuração de quantidade e valor da produção bruta e beneficiada de substâncias minerais. Brasília: DNPM/ DIDEM/ Divisão de Economia Mineral, 1998.

EMBRAPA - SNLCS (Serviço Nacional de Levantamento e Conservação de Solos). Práticas de conservação do solo. Rio de Janeiro: EMBRAPA, 1980. 88p. (Miscelânea, 3).

FENZL, N. Metabolismo social e econômico. Belém: Núcleo de Altos Estudos Amazônicos / Universidade Federal do Pará, 1995a Notas de aulas proferidas no Curso de Doutorado em Desenvolvimento Sustentável do Trópico Úmido.

FENZL, N. Conceitos gerais em Teoria de Sistemas. Belém: Núcleo de Altos Estudos Amazônicos / Universidade Federal do Pará, 1995b. Notas de aulas proferidas no Curso de Doutorado em Desenvolvimento Sustentável do Trópico Úmido.

FENZL, N. Considerations about interaction and exchange of information between open and self-organized systems. World Futures, Amsterdam, v. 49, p. 401-408, 1997a.

FENZL, N. Estudo de parâmetros capazes de dimensionar a sustentabilidade de um processo de desenvolvimento. In: XIMENES, Tereza (Org.). Perspectiva do desenvolvimento sustentável: uma contribuição para a Amazônia 21. Belém: Universidade Federal do Pará / Núcleo de Altos Estudos Amazônicos / Associação de Universidades Amazônicas, 1997b. 657p. p.1-31.

FENZL, N. (1998). O conceito de desenvolvimento sustentável em sistemas abertos. Belém: NUMA/UFPA, 1998. Textos de aulas proferidas no IV Curso de Especialização em Educação Ambiental.

FISCHER-KOWALSKI, M. et. alii. Causer related environmental indicators: a contribution to the environmental satellite-system of the Austrian SNA. Wien: IFF, 1991 (Research Report IFF - Soziale Ökologie, n. 17).

FISCHER-KOWALSKI, M.; HABERL, H.; PAYER, H. A paradise for paradigms: outlining an information system on physical exchanges 
José Alberto da Costa Machado, Norbert Fenzl

between the economy e nature. Wien: IFF, 1992 (Research Report IFF - Soziale Ökologie, n. 22).

FISCHER-KOWALSKI, M.; HABERL, H. Purposive interventions into lifeprocess: a neglected environmental dimension of the societynature-relationship. Wien: IFF, 1992 (Research Report IFF - Soziale Ökologie, n. 24).

FISCHER-KOWALSKI, M.; HABERL, H. Metabolism and colonisation: modes of production e the physical exchange between societies e nature. Wien: IFF, 1993 (Research Report IFF - Soziale Ökologie, n. 32).

FISCHER-KOWALSKI, M.; HABERL, H. On the cultural evolution of social metabolism with nature: sustainability problems quantified. Wien: IFF, 1994 (Research Report IFF - Soziale Ökologie, n. 40).

FISCHER-KOWALSKI, M. Metabolism and Communication: towards a common epistemological framework for social and natural processes. 1997. Conference on "Science for sustainable society - integrating natural and social sciences" at Roskilde University, Oct. 26-29. Vienna: IFF - Social Ecology.

FISCHER-KOWALSKI, M. Society's Metabolism: The Intellectual History of Material Flow Analysis. Part I: 1860-1970. Journal of Industrial Ecology, v. 2, n. 1, p. 61-78, 1998.

FISCHER-KOWALSKI, M. Society's Metabolism: The Intellectual History of Material Flow Analysis. Part II: 1970-1998. Journal of Industrial Ecology, v. 2, n. 4: 107-136, 1999a.

FISCHER-KOWALSKI, M. Material Flow Accounting (MFA): Information Package. Vienna: OAR-Regionalberatung GmbH, Amazônia 21 Project, 1999b. 31p.

GIDDENS, A. As conseqüências da modernidade. São Paulo: Editora da Universidade Estadual Paulista, 1991.

HIGUCHI, N. et alii. Biomassa na parte aérea da vegetação da floresta tropical úmida de terra-firme da amazônia brasileira. In: HIGUCHI, Niro (Org). Biomassa e Nutrientes Florestais - Projeto BIONTE - Relatório Final. Manaus: MCT-Instituto Nacional de Pesquisas da Amazônia/ UK-Department for International Development, 1997a. 345p.

HIGUCHI, Niro et alii. Crescimento e incremento de uma floresta amazônica de terra-firme manejada experimentalmente. In: HIGUCHI, 
Niro (Org). Biomassa e Nutrientes Florestais: Projeto BIONTE Relatório Final. Manaus: MCT-Instituto Nacional de Pesquisas da Amazônia / UK-Department for International Development, 1997b. 345p.

IBAMA (Instituto Brasileiro do Meio Ambiente e dos Recursos Naturais Renováveis).. ESTATPESCA. Relatório Interno. Brasília: IBAMA, 1995.

IBGE (Fundação Instituto Brasileiro de Geografia e Estatística). AEB Anuário Estatístico do Brasil. Rio de Janeiro: IBGE / Gerência de Documentação e Biblioteca, 1976-96.

INFORMAÇÕES agrícolas do IAC (Instituto Agronômico de Campinas). Folha de São Paulo, São Paulo, 11 abr. 1989.

LASZLO, Ervin. The systems view of the world: a holistic vision for our time. New Jersey: Hampton Press, 1996. 103p.

LIMA, Deborah. Conferência sobre a noção polissêmica do desenvolvimento sustentável. In: SIMPÓSIO INTERNACIONAL: AMAZÔNIA - ESTRATÉGIAS DE DESENVOLVIMENTO SUSTENTÁVEL EM DEBATE, 1997, Belém. Anais... Belém: FASE, NAEA/UFPA, SACTES/ DED, FAOR, UNIPOP, CPT/PA, FETAGRI/PA/AP, MPST e ABONG, 1997.

LUBCHENCO, Jane (1998). Entering the Century of the Environment: a new social contract for science. Science, v. 279, p. 491-497, jan.1998.

LUHMANN, N. Sistemas Sociales: Lineamentos para una teoria general. Trad. Silvia Pappe y Brunhilde Erker; coord. por Javier Torres Nafarrete. Rubi (Barcelona): Antrophos; México: Universidad Iberoamericana; Santafé de Bogotá: CEJA, Pontifícia Universidad Javeriana, 1998. 445 p. (Autores, Textos e Temas. Ciências Sociais, 15)

MACHADO, J. A. C. A sustentabilidade do desenvolvimento e a expressão energético material dos processos econômicos. Belém: Universidade Federal do Pará. Núcleo de Altos Estudos Amazônicos, 1998a. Projeto de Tese de Doutoramento.

MACHADO, J. A. C. Metabolismo sócio-econômico e colonização: uma metodologia operacional para medição da sustentabilidade. Belém: Universidade Federal do Pará / Nucleo de Altos Estudos Amazônicos, 1998b (Paper do NAEA, 80). 
José Alberto da Costa Machado, Norbert Fenzl

MACHADO, J. A. C. A sustentabilidade do desenvolvimento e a demanda material do sistema econômico. 1999. Tese (Doutoramento em ) - Núcleo de Altos Estudos Amazônicos, Universidade Federal do Pará, Belém. 1999.

MARTIN, L. C. Tayarol. Nutrição mineral de bovinos de corte. São Paulo: Ed. Nobel, 1993..

MATHIS, A. (1997). O fim da supremacia da política: possibilidades e limites da intervenção do Estado na interpretação da teoria de sistemas. Belém: Universidade Federal do Pará / Núcleo de Altos Estudos Amazônicos, 1997. Notas de aula no Programa de Doutorado em Desenvolvimento Sustentável do Trópico Úmido.

MENDES, A. D.; SACHS, I.. A inserção da Amazônia no mundo. In: CONFERÊNCIA INTERNACIONAL AMAZÔNIA 21: UMA AGENDA PARA UM MUNDO SUSTENTÁVEL, 1, 1997, Brasilia, DF.. Anais... Brasília: DMF Congresso, 1998. 264p, p.35-44.

MUSEU EMÍLIO GOELDI. Texto para Workshop de Janeiro 99 - Area Temática: Agricultura Sustentável. Consórcio Museu Emilio Goeldi/Fundação Aplicações Tecnológicas Críticas/Universidade de São Paulo - Programa de Pós-Graduação de Ciências Ambientais, 1999. 116p. Disponível em: < http://www.atech.br/agenda21.as>. Acesso em: 23 jan.1999.

MYER, H. La tecnificación del mundo: origen, esencia y peligros. Versión española de Rafael de la Vega. Madrid: Editorial Gredos, 1966. $410 p$.

NBER (National Bureau of Economic Research). NBER Online Data. The PENNWorld Table (Mark 5.6), 1996. Disponível em: < http:// www.nber.org/data index.html>.

NEVES, A. R. Tópicos de Educação Florestal. Belo Horizonte: Empresa de Assistência Técnica e Extensão Rural do Estado de Minas Gerais, 1980. 162p.

NORGAARD, R. B. (1992). Towards economics that sustain nature and human dignity: one perspective from the United States. In: THE NEW economic paradigm: a sustainable economy. Austria: Technische Universitat, 1992. p.19-39.

NUNES, B. Um conceito de cultura. In: XIMENES, Tereza (Org.). Perspectiva do desenvolvimento sustentável: uma contribuição para a Amazônia 21. Belém: Universidade Federal do Pará / Núcleo de 
Altos Estudos Amazônicos / Associação de Universidades Amazônicas, 1997. 657p. p. 531-551.

OECD (Organization for European Comunity Development). Core set of indicators for environmental performance reviews: a synthesis report by the group on the State of the Environment. Paris: OECD, 1993 (Environment. Monographs, n. 83).

PRIGOGINE, I.; STENGERS, I. A nova aliança: a metamorfose da ciência. Tradução de Miguel Faria e Maria Joaquina Machado Trincheira. Brasília: Editora Universidade de Brasília, 1984.

RAPOPORT, A. Aspectos matemáticos da análise geral dos sistemas. In: Teoria dos sistemas. Tradução de Maria da Graça Lustosa Becskeházy. Rio de Janeiro: Editora da Fundação Getúlio Vargas, 1976. 143 p. p.21-46.

SECTMA (Secretaria de Ciência e Tecnologia e Meio Ambiente do Acre). Critérios de sustentabilidade da produção florestal. Documento final. Rio Branco, Acre, Brasil, 1997.

SPANGENBERG, J. H. Integracion de critérios en el concepto de sostenibilidad. Espacios, Costa Rica, n. 7, Enero/Junho 1996a.

SPANGENBERG, J. H. Towards an integrated concept of sustainability. 1996b. Paper apresentado no Simpósio Internacional "Amazônia: Estratégias para o Desenvolvimento Sustentável em Debate", Belém, Pará, Brasil, 08-11 set. 1996.

SPANGENBERG, J. H.; BONNIOT, Odile. Sustainability Indicators: a compass on the Road Towards Sustainability. Technical Report. Wuppertal, Germany: Wuppertal Institute for Climate, Environment, Energy. Division for Material Flows and Structural Change, 1997.

SPANGENBERG, J. H.; SCHMIDT-BLEEK, Friedrich. How to probe the physical boundarie for sustainable society? Foundations of sustainable development. Ethic, law, culture and the physical limits. Uppsala, Sweden: Uppsala University, 1997.

TEIXEIRA, L. Comunicação Pessoal. Belém: EMBRAPA / Centro de Pesquisas Agroflorestais da Amazônia Oriental, 1998.

UHL, C. et alii. Impactos da atividade madeireira e perspectivas para o manejo sustentável da floresta numa velha fronteira da Amazônia: o caso Paragominas. In: ALMEIDA, O. (org.). Evolução da fronteira amazônica: oportunidades para um desenvolvimento sustentável. Porto Alegre: Edições Caravela, 1996. 140p. 
José Alberto da Costa Machado, Norbert Fenzl

UN (United Nations). International Comparison Programme. Handbook of The International Comparison Programme, 1992. Disponível em: < http://www.un.org/depts/unsd/sna/icp/index.html > ..

UN (United Nations). International Comparison Programme. World Comparison of Real Gross Domestic Product and Purchasing Power (1985), 1994. Disponível em: < http://www.un.org/depts/unsd/sna/ icp/index.html $>$.

UNDP (United Nation's Development Program). Human Development Report 1996. New York: UNDP, 1996.

US-BC (U.S.Bureau of the Census). International Data Base (IDB). Washington: International Programs Center (IPC) / Bureaus of the Census, 1998. Disponível em: < http://www.census.gov/ftp/pub/ipc/ www/idbrank.html>.

VIEIRA, M. N. F. et alii. Levantamento e conservação do solo. Belém: FCAP. Serviço de Documentação e Informação, 1996. 320p.

WORLD BANK. Monitoring Environmental Progress: a report on work in progress. Washington DC, 1985.

WRI (World Resource Institute) et alii. World Resource (1996-97). New York: Oxford University Press, 1996.

YARZA, F. I. S. Dicionário Griego-Español. Barcelona: Ed. Ramón Sopena, 1985. 
Anexo-02 - Resumo das características relevantes das DMTs do Brasil, EUA, Alemanha, Japão e Holanda (tons)

\begin{tabular}{|c|c|c|c|c|c|}
\hline Características relevantes & BRASIL (1995) & EUA (1994) & $\begin{array}{c}\text { ALEMANHA } \\
\text { (1994) }\end{array}$ & JAPÃO (1994) & HOLANDA (1994) \\
\hline Demanda Material Total (DMT) & 3.238 .304 .000 & 19.304 .000 .000 & 5.411 .370 .000 & 4.019 .700 .000 & 979.637 .000 \\
\hline Variação da DMT no período & $65,5 \%$ & $13,1 \%$ & $42,2 \%$ & $34,7 \%$ & $42,5 \%$ \\
\hline \multicolumn{6}{|l|}{ Segundo origem } \\
\hline Doméstica & $92,3 \%$ & $92,3 \%$ & $64,1 \%$ & $32,7 \%$ & $31,2 \%$ \\
\hline Importada & $7,7 \%$ & $7,7 \%$ & $35,9 \%$ & $67,3 \%$ & $68,8 \%$ \\
\hline \multicolumn{6}{|l|}{ Segundo natureza } \\
\hline Reconhecida & $43,1 \%$ & $32,2 \%$ & $35,7 \%$ & $49,2 \%$ & $56,0 \%$ \\
\hline Ignorada & $56,9 \%$ & $67,8 \%$ & $64,3 \%$ & $50,8 \%$ & $44,0 \%$ \\
\hline \multicolumn{6}{|l|}{ Segundo classes } \\
\hline Não-Renováveis & $28,9 \%$ & $72,3 \%$ & $76,7 \%$ & $88,1 \%$ & $52,0 \%$ \\
\hline Renováveis & $36,6 \%$ & $8,2 \%$ & $6,8 \%$ & $6,4 \%$ & $29,9 \%$ \\
\hline Erosão de Solo & $33,4 \%$ & $17,6 \%$ & $2,4 \%$ & $4,0 \%$ & $0,1 \%$ \\
\hline Material Industr. sem Enquadramento & $1,0 \%$ & $1,9 \%$ & $14,1 \%$ & $1,5 \%$ & $18,0 \%$ \\
\hline Relação DMT-Brasil e demais países & 1 & 0,16 & 0,59 & 0,80 & 3,30 \\
\hline PIB (dólar-ppp, preço constante, 1985) & 634.420 & 4.824 .231 & 1.110 .078 & 1.916 .630 & 213.026 \\
\hline Relação PIB-Brasil e demais países & 1 & 0,13 & 0,57 & 0,33 & 2,98 \\
\hline Variação do PIB no período & $67,5 \%$ & $63,3 \%$ & $87,0 \%$ & $97,2 \%$ & $52,0 \%$ \\
\hline População & 163.113 .370 & 260.602 .289 & 81.612 .677 & 124.991 .070 & 15.382 .198 \\
\hline Rel. população-Brasil e demais países & 1 & 0,63 & 2,00 & 1,31 & 10,60 \\
\hline Variação da população no período & $49,9 \%$ & $20,7 \%$ & $32,0 \%$ & $12,0 \%$ & $12,7 \%$ \\
\hline PIB per capita (dólar-ppp/pessoa) & $3.889,44$ & $18.511,85$ & $13.601,78$ & $15.334,14$ & $13.848,87$ \\
\hline Variação do PIB per capita no período & $11,7 \%$ & $35,3 \%$ & $41,6 \%$ & $76,0 \%$ & $34,9 \%$ \\
\hline DMT por unidade do PIB (milhão/ton) & 5.104 & 4.001 & 4.875 & 2.097 & 4.599 \\
\hline Variação DMT/unidade PIB no período & $0 \%$ & $-30,7 \%$ & $-23,9 \%$ & $-31,7 \%$ & $-6,2 \%$ \\
\hline DMT per capita (ton/pessoa) & 19,85 & 74,07 & 66,31 & 32,16 & 63,69 \\
\hline Variação da DMT per capita no período & $11,7 \%$ & $-6,3 \%$ & $7,7 \%$ & $20,2 \%$ & $26,4 \%$ \\
\hline
\end{tabular}

